OPEN ACCESS

Edited by:

lan Marriott,

University of North Carolina at

Charlotte, United States

Reviewed by:

Mark Ambrose,

University of Tasmania, Australia

Amy Rasley,

Lawrence Livermore National Laboratory (DOE), United States

*Correspondence:

Rostyslav Bilyy

r.bilyy@gmail.com

Julie M. J. Bouckaert

julie.bouckaert@univ-lille1.fr

tThese authors have contributed equally to this work.

¥These authors have contributed equally as senior authors.

Specialty section:

This article was submitted to Microbial Immunology, a section of the journal Frontiers in Microbiology

Received: 20 October 2017 Accepted: 29 March 2018 Published: 18 April 2018

Citation:

Dumych T, Yamakawa N, Sivignon A,

Garenaux E, Robakiewicz S, Coddeville B, Bongiovanni A, Bray $F$, Barnich N, Szunerits S, Slomianny C, Herrmann M, Gouin SG, Lutsyk AD,

Munoz LE, Lafont F, Rolando C, Bilyy R and Bouckaert JMJ (2018)

Oligomannose-Rich Membranes of

Dying Intestinal Epithelial Cells

Promote Host Colonization by

Adherent-Invasive E. coli.

Front. Microbiol. 9:742.

doi: 10.3389/fmicb.2018.00742

\section{Oligomannose-Rich Membranes of Dying Intestinal Epithelial Cells Promote Host Colonization by Adherent-Invasive E. coli}

Tetiana Dumych ${ }^{1 \dagger}$, Nao Yamakawa ${ }^{2 \dagger}$, Adeline Sivignon ${ }^{3 \dagger}$, Estelle Garenaux ${ }^{3}$, Stefania Robakiewicz ${ }^{2}$, Bernadette Coddeville ${ }^{2}$, Antonino Bongiovanni ${ }^{4}$, Fabrice Bray ${ }^{5}$, Nicolas Barnich ${ }^{3}$, Sabine Szunerits ${ }^{6}$, Christian Slomianny ${ }^{7}$, Martin Herrmann ${ }^{8}$, Sébastien G. Gouin ${ }^{9}$, Alexander D. Lutsyk ${ }^{1}$, Luis E. Munoz ${ }^{8}$, Frank Lafont ${ }^{4}$, Christian Rolando ${ }^{5}$, Rostyslav Bilyy ${ }^{1 * \neq}$ and Julie M. J. Bouckaert ${ }^{2 * \neq}$

${ }^{1}$ Department of Histology, Cytology and Embryology, Danylo Halytsky Lviv National Medical University, Lviv, Ukraine, ${ }^{2}$ Unité de Glycobiologie Structurale et Fonctionnelle, UMR8576 Centre National de la Recherche Scientifique, University of Lille, Villeneuve d'Ascq, France, ${ }^{3}$ Université Clermont Auvergne, Institut National de la Santé et de la Recherche Médicale U1071, USC-INRA 2018, M2iSH, Clermont-Ferrand, France, ${ }^{4}$ Cellular Microbiology and Physics of Infection Group-Center of Infection and Immunity of Lille, Institut Pasteur de Lille, Centre National de la Recherche Scientifique UMR8204, INSERM U1019, Lille Regional Hospital University Centre, University of Lille, Lille, France, ${ }^{5}$ Miniaturisation pour l'Analyse, la Synthèse et la Protéomique, USR 3290 Centre National de la Recherche Scientifique, University of Lille, Villeneuve d'Ascq, France, ${ }^{6}$ Institut Supérieur de l'Electronique et du Numérique, University of Lille, Centrale Lille, UMR 8520-IEMN, University Valenciennes, Lille, France, ${ }^{7}$ Laboratoire de Physiologie Cellulaire, Institut National de la Santé et de la Recherche Médicale U.1003, University of Lille, Villeneuve d'Ascq, France, ${ }^{8}$ Department of Internal Medicine 3-Rheumatology and Immunology, Friedrich-Alexander-University Erlangen-Nürnberg and Universitätsklinikum Erlangen, Erlangen, Germany, ${ }^{9}$ Chimie Et Interdisciplinarité, Synthèse, Analyse, Modélisation, UMR 6230 Centre National de la Recherche Scientifique, Université Nantes Angers Le Mans (L'UNAM), Nantes, France

A novel mechanism is revealed by which clinical isolates of adherent-invasive Escherichia coli (AIEC) penetrate into the epithelial cell layer, replicate, and establish biofilms in Crohn's disease. AlEC uses the FimH fimbrial adhesin to bind to oligomannose glycans on the surface of host cells. Oligomannose glycans exposed on early apoptotic cells are the preferred binding targets of AIEC, so apoptotic cells serve as potential entry points for bacteria into the epithelial cell layer. Thereafter, the bacteria propagate laterally in the epithelial intercellular spaces. We demonstrate oligomannosylation at two distinct sites of a glycoprotein receptor for AIEC, carcinoembryonic antigen related cell adhesion molecule 6 (CEACAM6 or CD66c), on human intestinal epithelia. After bacterial binding, FimH interacts with CEACAM6, which then clusters. The presence of the highest-affinity epitope for FimH, oligomannose-5, on CEACAM6 is demonstrated using LC-MS/MS. As mannose-dependent infections are abundant, this mechanism might also be used by other adherent-invasive pathogens.

Keywords: CEACAM6, adherent-invasive E. coli, apoptotic cell-derived membranous vesicles, oligomannose glycans, Crohn's disease 


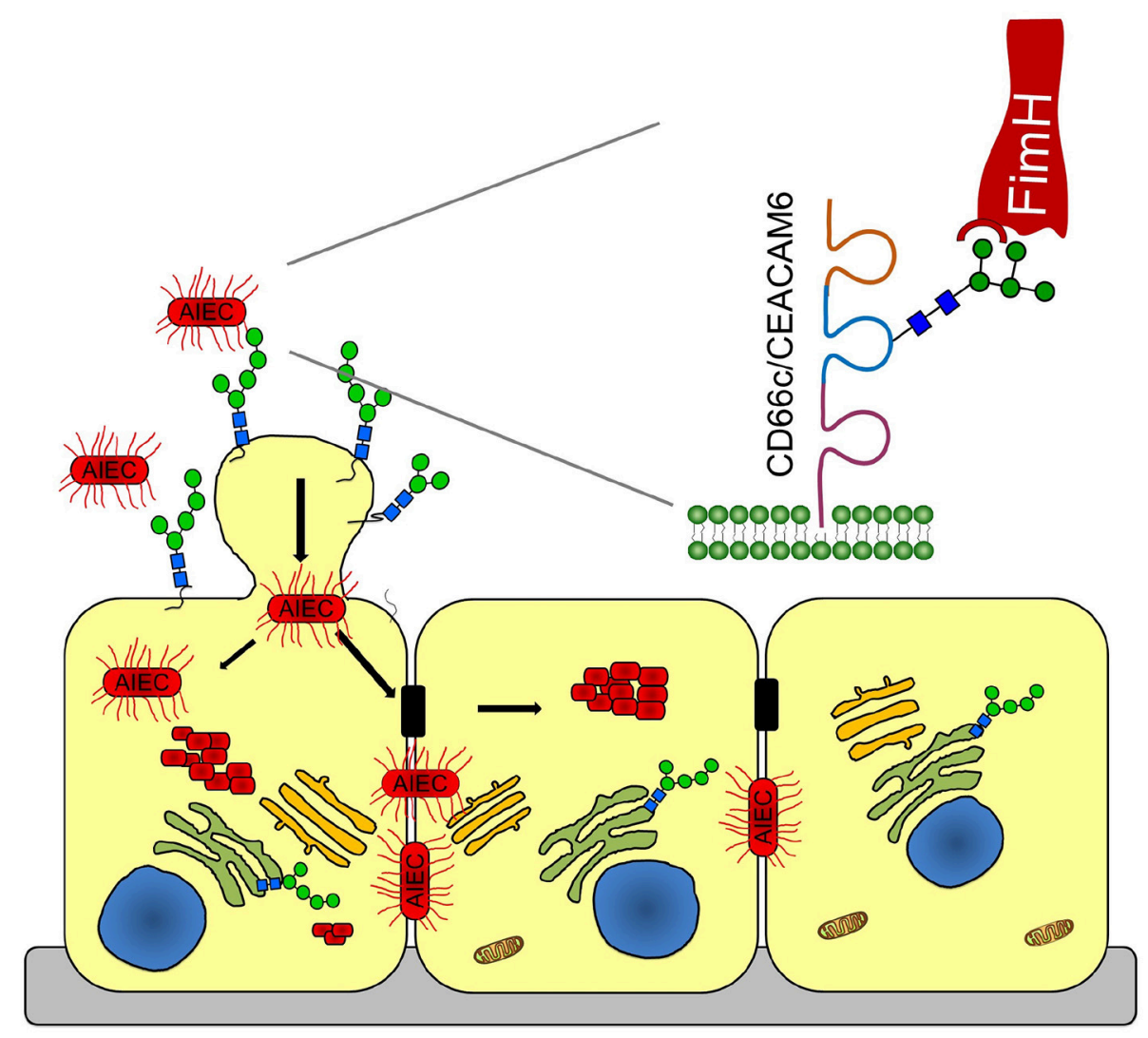

GRAPHICAL ABSTRACT | A Sweet Shuttle for Adherent-Invasive Escherichia coli Through Epithelial Membranes.

\section{INTRODUCTION}

Microbes express an arsenal of virulence factors with which they highjack the normal functions of the host. A well-known example of those functions is cell-cell adhesion. The adaptive immune response of the host can interfere with the microbe's recognition and binding of cell adhesion molecules, but adaptive immune responses are slow to develop after initial exposure to a new pathogen. Specific clones of $\mathrm{B}$ and $\mathrm{T}$ cells have to be activated and expanded, and it can take up to a week before adaptive immune responses are effective. During the first hours and days following exposure to a pathogen, the innate immune system provides protection. Unlike adaptive immune responses, innate immune responses are not pathogen-specific, and rely notably on complement proteins to evoke signaling aimed at eliminating the invaders. Complement activation leads to disruption of the microbial membrane, which attracts phagocytes and leads to an inflammatory response. The phagocytic cells secrete degradative enzymes, antimicrobial peptides, and reactive oxygen species aimed at killing the invading microbes. Uropathogenic E. coli (UPEC), which are the causal agents of most urinary tract infections (UTIs), express virulence factors that allow them to colonize mammalian bladder cells (Stamm, 2002; Laupland et al., 2007). Adherent-invasive E. coli (AIEC) strains, which are associated with microbial dysbiosis in $37 \%$ of Crohn's disease (CD) patients (Darfeuille-Michaud et al., 1998, 2004), share a phylogenetic link with UPEC (Miquel et al., 2010). Both AIEC and UPEC strains can adhere to and interact with receptors on the epithelial linings of the gastrointestinal tract. They use the same protein surface appendages, namely, type 1 fimbriae with oligomannose-specific lectin FimH at their tips (Martinez et al., 2000; Kline et al., 2009), making them highly invasive. For the fimH gene, the prototypic E. coli strains LF82 and UTI89 are classified in the same phylogenetic group (Miquel et al., 2010; Conte et al., 2016) known as AIEC, which was used in this work.

Eukaryotic cells release vesicles under different conditions, such as apoptosis, stress, communication, and transportation (van der Pol et al., 2012). When superficial urothelial cells become infected with type-1 fimbriated, FimH-positive E. coli, the underlying cell layer undergoes accelerated cell proliferation and differentiation in response to bone morphogenetic protein 4 signaling (Mysorekar et al., 2009). Because of this efficient system of bacterial elimination through boosted epithelial renewal, invasive pathogens are more likely to infect patients with metabolic diseases associated with increased apoptosis, such as diabetes mellitus (Geerlings et al., 2002; Taganna et al., 2011). Apoptosis is a programmed and regulated physiological process of cell death that plays an essential role in tissue turnover. During 
apoptosis, cells shrink and compact themselves by directing superfluous materials into apoptotic blebs, named apoptotic cellderived membranous vesicles (ACMV). Recently, we showed that apoptotic cells release two distinct types of ACMV, derived either from the endoplasmic reticulum (ER) or from the plasma membrane (PM) (Bilyy et al., 2012). ER-derived ACMV carrying immature glycoproteins are potentially important for FimHmediated bacterial adhesion, analogous to the macrophage system where the oligomannosidic glycans exposed on apoptotic cells and ACMV serve as an antenna for macrophage recognition (Tomin et al., 2015).

The human adhesion molecule, carcinoembryonic antigenrelated cell adhesion molecule 6 (CEACAM6, also known as CD66c or NCA) favors colonization by AIEC; its gene expression is upregulated by inflammatory cytokines and possibly by microbes (Chassaing et al., 2011). CEACAM6 is a complex, highly glycosylated protein that belongs to the large immunoglobulin (Ig) superfamily and consists of one IgV-like and two IgC2-like domains (Thompson et al., 1991). The ceacam6 gene is overexpressed in most carcinomas, including those of the gastrointestinal, respiratory and genitourinary tracts (Gemei et al., 2013). Increased serum levels of CEACAM6 serve as prognostic indicators of chronic inflammation in $C D$ patients, given that no CEACAM6 production and mannosylation were observed in healthy ileal mucosa (Barnich et al., 2007). In more than $35 \%$ of $\mathrm{CD}$ patients with ileal involvement, the abundance of mannosidic structures at the ileal mucosa is elevated due to overexpression of ceacam6 by ileal epithelial cells, which favors AIEC colonization. In turn, AIEC colonization induces increased ceacam 6 expression, thus further facilitating colonization. Recently, a discrepancy between the predicted and observed molecular weights of CEACAM6 led to the identification of a glycosylation site at Asn-197 containing a paucimannosidic glycan (Thaysen-Andersen et al., 2015). In parallel, it has been reported that AIEC effectively binds oligomannose glycans (Brument et al., 2013). However, a deeper understanding of the interaction between host cells and AIEC is needed in order to combat AIEC infections. Here, we follow how AIEC interacts with oligomannosidic receptors upon infection of human intestinal Caco-2 cells and then spreads in epithelial cells to promote its survival, replication and biofilm formation (Oligomannose-rich membranes of dying cells promote host cell colonization, Graphical Abstract).

\section{RESULTS}

\section{Effect of fimH-Expressing $E$. coli on the Infection of Human HeLa Cells}

The binding of $E$. coli to epithelial cells is mediated by the type-1 fimbrial adhesin FimH (Hultgren et al., 1991; Martinez et al., 2000). FimH is involved in the induction of apoptosis (Klumpp et al., 2006; Thumbikat et al., 2009) and we asked whether FimH-induced apoptosis coincides with the occurrence of oligomannosidic glycans. Bleb production was prominent in HeLa cells upon interaction with the type-1 fimbriated E. coli UTI89 strain. Differential interference contrast (DIC) microscopy allowed visualization of bacterial infection of ACMV (Figure 1A). Oligomannosidic glycans on the surface of ACMV were detected using the mannose-specific lectin, Narcissus pseudonarcissus (NPL), conjugated with fluorescein isothiocyanate (FITC) (Figure 1B). Since bacterial binding to oligomannosidic glycans is mediated by the FimH adhesin (Bouckaert et al., 2006), purified FimH lectin domain $(10 \mu \mathrm{g} / \mathrm{mL}$ ) was added to HeLa cells and cell viability was analyzed using annexin V-FITC/propidium iodide (PI) fluorescent staining. DIC images showed abundant bleb formation on the surfaces of the human epithelial cells as early as $2 \mathrm{~h}$ after treatment with the FimH lectin. The number of annexin V-positive blebs, which resembled apoptotic vesicles (ACMV), increased with time (Figure 1C).

MALDI-TOF MS/MS spectra (tandem mass spectrometry) were used to characterize $\mathrm{N}$-glycans obtained from isolated membranous vesicles. HeLa cells or the colonic epithelial cells Caco-2 were exposed to FimH. UV-B irradiation served as a positive control for ACMV formation and no irradiation served as a negative control. As shown in the results obtained using Caco-2 cells, the membranous vesicles produced by the cells exposed to FimH possessed oligomannose- $5(\mathrm{~m} / \mathrm{z}=1579.7)$ and oligomannose-7 glycans $(\mathrm{m} / \mathrm{z}=1987.9)$ (Figure 2A), like the ACMV induced by UV-B irradiation [oligomannose- 5 and oligomannose-8 glycans $(\mathrm{m} / \mathrm{z}=2192.0)$ ] (Figure 2B). No oligomannosidic glycans were detected in the membranous vesicles (exosomes, blebs) produced by the untreated cells under normal circumstances. These results are similar to those obtained with HeLa cells. (Figure S1). Western blot analysis of the bleb fraction of FimH-treated Caco-2 cells revealed that the mobility of CEACAM6 was similar to that of the proteins detected by NPL binding (Figure 2C). Staining of Caco-2 cells with FimHFITC lectin confirmed their binding to subcellular membranous microvesicles or to ACMV, as well as to subpopulations of fullsized or shrunken cells (Figure 2D). Interestingly, high levels of CEACAM6 were present on immortalized cells of intestinal epithelial origin (Caco-2, HT29) and those cells can be used to extract and purify CEACAM6 (Figure S2), whereas much lower levels were present on HeLa cells (Figure S3). CEACAM6 levels were low or absent on primary human cells such as lymphocytes and monocytes.

\section{AIEC Infection Relies on Interaction of FimH With Mannose and Involves Bacterial Dissemination in the Intercellular Spaces}

Little is known about how AIEC infects epithelial cells. The AIEC LF82 strain, transformed with a plasmid coding for the near-infra red (NIR)-fluorescent protein TurboFP635, was co-incubated with Caco- 2 cells for $5 \mathrm{~h}$. Next, the cell co-culture was treated with gentamicin to kill extracellular bacteria, or left untreated (Figure 3A). Video lapse microscopy revealed that AIEC invaded Caco- 2 cell within $4-5 \mathrm{~h}$ after infection. During the progression of infection, E. coli was observed near intercellular junctions (Figure 3B and Figure S4). Upon invasion, the bacteria multiplied intracellularly and spread rapidly (Figure 3C). At the later stages of infection, the bacteria formed biofilms (Figure 3D). In the actively growing biofilm, the nucleoids of all bacteria were prominently stained with the DNA-specific dye 


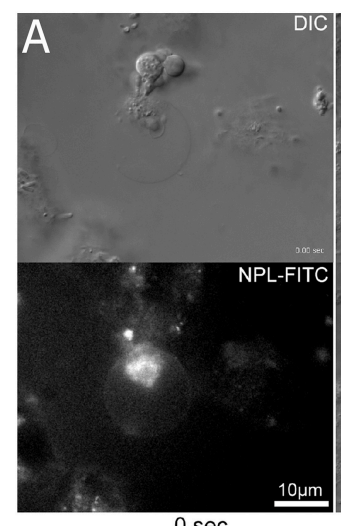

$0 \mathrm{sec}$

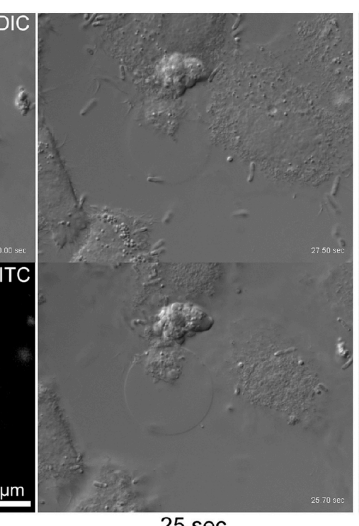

$25 \mathrm{sec}$

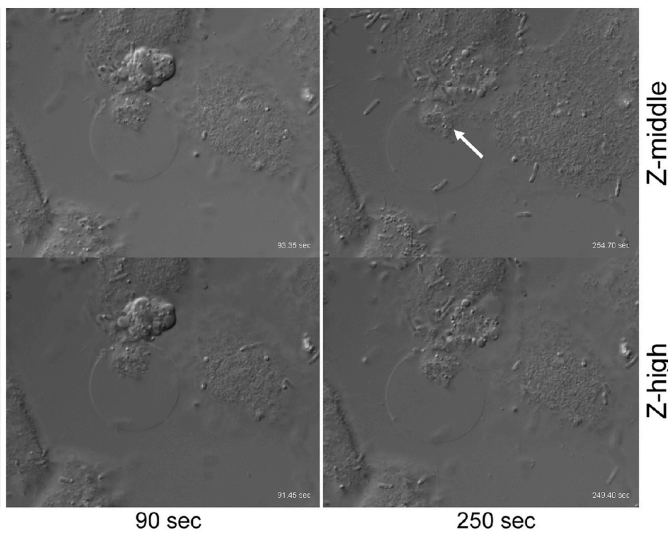

$\frac{0}{\frac{0}{0}}$
$\frac{0}{E}$
N
$\frac{\text { 을 }}{\text { N }}$

$6 h$
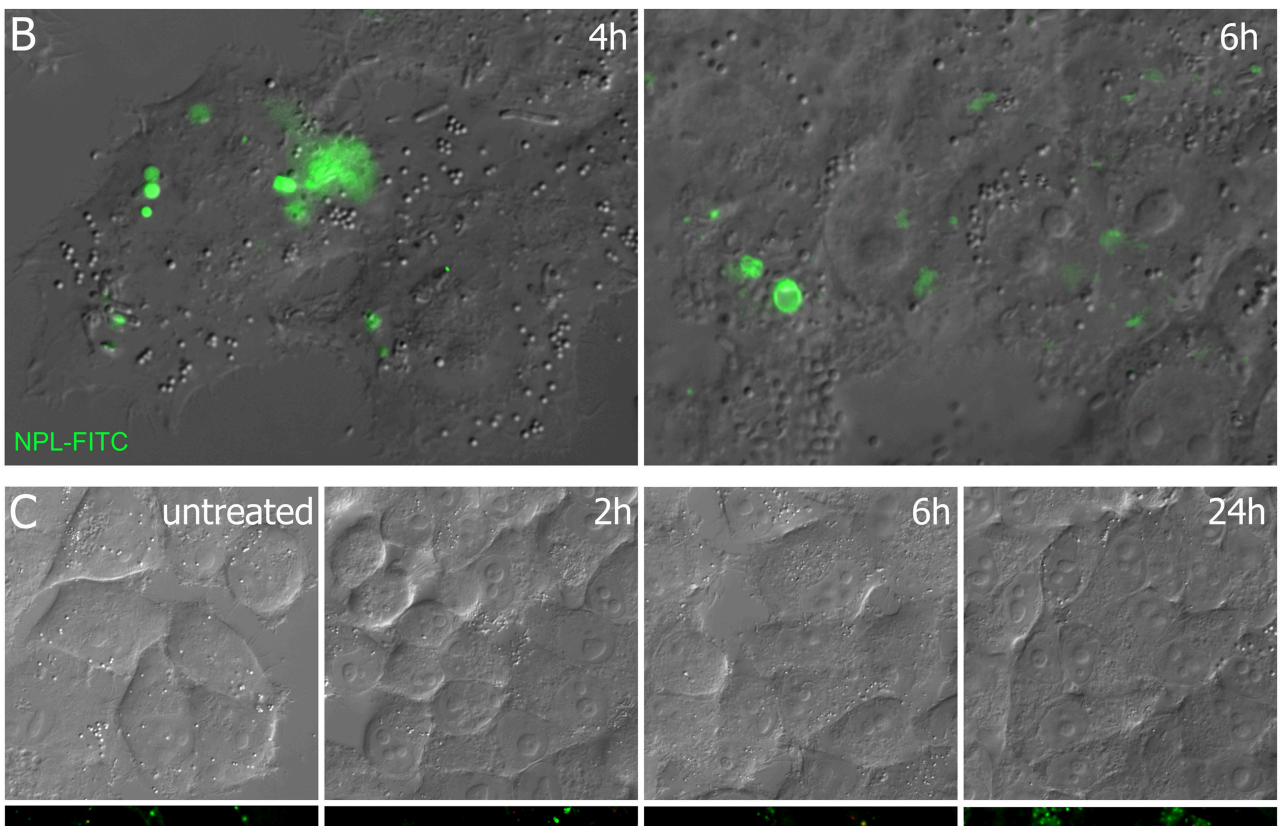

h
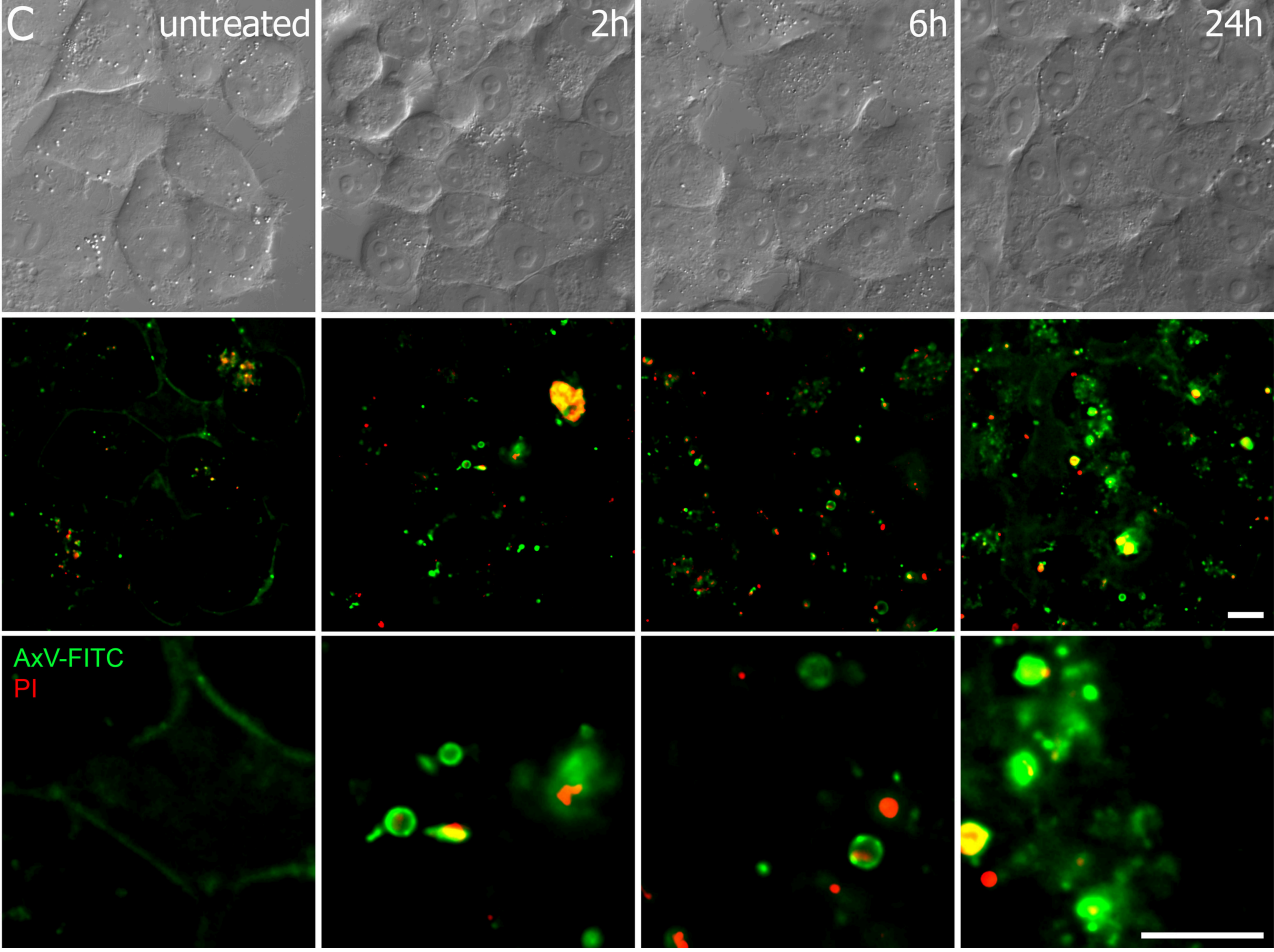

FIGURE 1 | Infection of HeLa cells with AIEC induces surface blebbing. (A) Video microscopy over a time course of several minutes, where AIEC that had been co-incubated for $6 \mathrm{~h}$ with HeLa cells attach to and then penetrate (arrow) into membranous vesicles of blebbing cells. (B) Co-incubation of HeLa cells with E. coli UTI89 cells resulted in the appearance of oligomannose-rich blebs, as visualized using NPL-FITC lectin in DIC and fluorescence microscopy (merged images).

(C) Bleb formation in HeLa cells treated with the FimH protein was observed as early as $2 \mathrm{~h}$ after infection. DIC imaging is shown in the upper row and fluorescence microscopy with annexin V-FITC (green) and PI (red) in the two lower rows. Scale bar $=10 \mu \mathrm{m}$. 

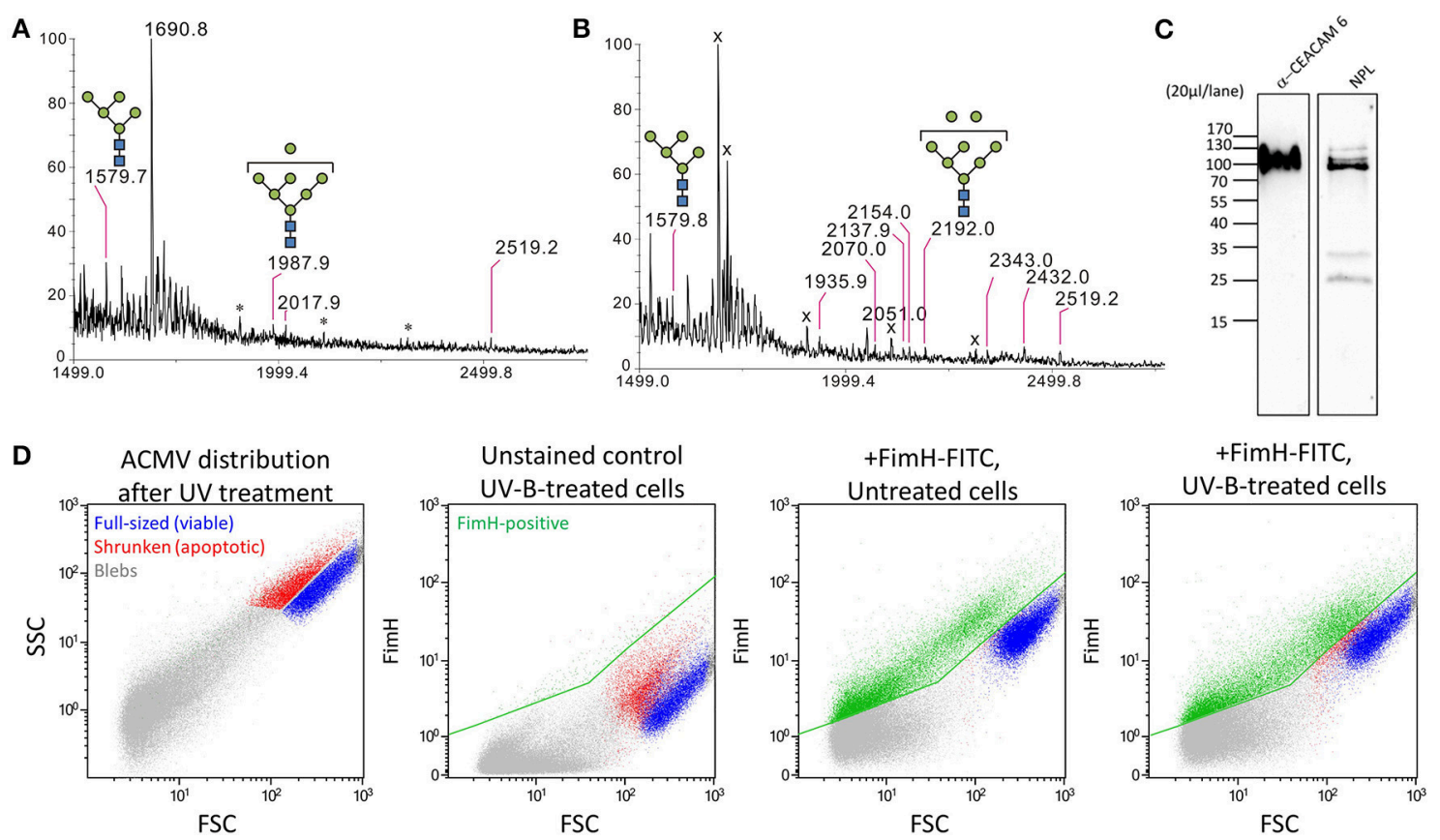

FIGURE 2 | FimH binds to ACMV-derived oligomannoside glycans. (A) FimH-induced blebs possess oligomannose-glycans, which are known FimH-binding targets, resemble the blebs (B) seen during early apoptosis induced by UV-B irradiation. (C) Western blot of FimH-induced blebs shows CEACAM6 and oligomannosidic residues detected by using antibodies and Narcissus pseudonarcissus lectin (NPL), respectively. (D) Flow cytometry of FimH binding to Caco-2 cells and their ACMV. Both apoptotic cells and ACMV are effectively bound by FimH-FITC lectin (positive population is colored green).

(DAPI), but only part of the population was already in a state to produce the TurboFP635 NIR-fluorescent protein. Similar to these results, time-lapse confocal microscopy on healthy Caco-2 cells (Figure 3E), performed without arresting extracellular bacterial growth, revealed the formation of intracellular bacterial communities and their propagation inside the intercellular spaces 6-19h after initial infection (Figure 3G and Figure S4). Bacterial binding and invasion and oligomannose exposure were abrogated in the non-piliated LF82- $\Delta$ fimH mutant (Figure 3F) and were diminished upon treatment with $500 \mathrm{nM}$ of the potent FimH lectin inhibitor, 2-( $\alpha$-D-mannopyranos-1-yl) amino-5-(4methyl-2-(pyrazin-2-yl)thiazole-5-carbonyl)thiazole (Brument et al., 2013; Figure 3H). This confirms that adhesion to and invasion of Caco-2 cells by LF82 bacteria depend on the interaction of FimH with mannose.

\section{AIEC Tends to Bind Dying Cells and ACMV Rich in Mannose}

When AIEC LF82 was incubated with epithelial cells previously committed to apoptosis, they preferentially bound apoptotic bodies and ACMV rich in mannosidic glycans (Figure 4). In some cases, AIEC used ACMV to penetrate into dying cells (Figures 1A, 4B). These observations indicated that bacteria used dying (apoptotic) cells to penetrate the epithelial cell layer, and that after using the less protected cell surface for invasion, they go beyond the zone of tight junctions of the polarized cells to spread via the lateral membranes (Figure 3B).

\section{CEACAM6 Mediates the Interaction of the FimH Adhesin With Host Cells}

To identify the molecular targets of AIEC binding, we examined the production of the CEACAM6 protein, which is involved in initiating cell signaling upon bacterial invasion (Barnich et al., 2007; Chassaing et al., 2011). Using structured illumination microscopy (SIM), we found CEACAM6 distributed in clusters on the surfaces of viable cells, apoptotic cells and ACMV (Figures 5A-C). Examination of early bacterial infection events by SIM demonstrated the clustering of CEACAM6 at the places of initial bacterial binding (Figure 5D). To investigate the possible interaction of bacteria with CEACAM6, we measured the ratio of the time-of-flight (TOF) of cells in fluorescence (FL) and forward scatter (FS) (Fürnrohr et al., 2015). Clustering and capping of cell surface receptors resulted in a decrease of the $\mathrm{TOF}_{\mathrm{FL}} / \mathrm{TOF}_{\mathrm{FS}}$ ratio (Figure $5 \mathrm{E}$ ). We stained Caco-2 cells with an anti-CEACAM6-PE antibody and immediately incubated them with AIEC or its component (FimH lectin). The $\mathrm{TOF}_{\mathrm{FL}} / \mathrm{TOF}_{\mathrm{FS}}$ ratio was measured for $10 \mathrm{~min}$ at $>15,000$ events per minute. The cells were treated with one of the following: AIEC LF82, AIEC LF82- $\Delta$ fimH mutant (negative control), $1 \mu \mathrm{m}$ polystyrene microparticles (MP) conjugated with FimH (FimH-MP) or $1 \mu \mathrm{m}$ polystyrene MP conjugated with FimA (major fimbrial subunit, negative control) (FimA-MP). For AIEC LF82 and FimH-MP, a significant decrease in $\mathrm{TOF}_{\mathrm{FL}} / \mathrm{TOF}_{\mathrm{FS}}$ ratio was observed for AIEC LF82 vs. AIEC LF82- $\Delta$ fimH $(p=0.002)$, and for FimH-MP vs. FimA-MP $(p=0.006)$, indicating that FimH-bearing 

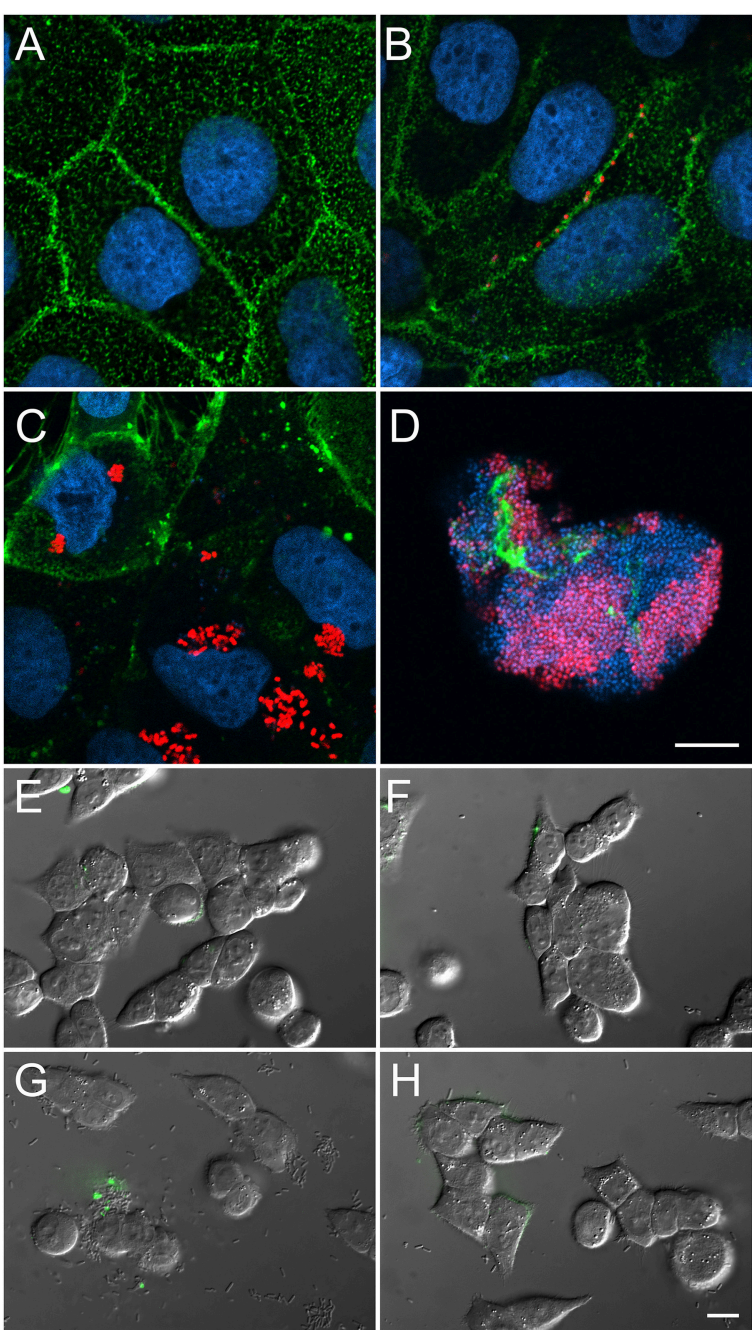

FIGURE 3 | Bacterial colonization of Caco-2 cells requires surface exposure of the oligomannose. Bacteria penetrate through the intercellular spaces and then invade the cells. Their binding is dependent on FimH-oligomannose interactions. Nuclear DNA was visualized with DAPI staining (blue) and cell membranes were stained with fluorescent wheat germ agglutinin (WGA-FITC) (green, A-D). E. coli was transformed with a plasmid encoding NIR-fluorescent protein TurboFP635 (red, A-D). (A) Semi-confluent uninfected Caco-2 cells. $(\mathbf{B}, \mathbf{C})$ Caco-2 cells infected with $E$. coli LF82 for $5 \mathrm{~h}$ and treated with gentamicin for $19 \mathrm{~h}$. (D) Infection for $24 \mathrm{~h}$ with LF82 without gentamicin treatment. (E) Untreated cells. (F) Infection with E. coli LF82- $\Delta$ fimH. (G) Wild-type E.coli LF82 and (H) E.coli LF82 co-incubated with $500 \mathrm{nM}$ of a thiazolylamine mannose-based inhibitor. (E-H) NPL-FITC was used to visualize oligomannosidic glycans (green, overlayed). Scale bar $=10 \mu \mathrm{m}$.

bacteria and microparticles caused CEACAM6 clustering (Figure 5F).

\section{Two Oligomannosidic Glycans at Asn-197 and Asn-224 of the Middle Domain of CEACAM6 as Potential Receptors of the FimH Adhesin}

Since bacteria rely on mannose-based interaction with surface targets on host cells (Barnich et al., 2007), we examined the glycosylation of CEACAM6. First, MALDI TOF/TOF MS analysis was performed on permethylated $N$-linked glycans of CEACAM6 isolated from IFN $\gamma$-stimulated Caco-2 cells (mimicking inflammatory conditions). We confirmed the presence of distinct oligomannose glycans in CEACAM6, including oligomannose-5 possessing the highest affinity for FimH (Figure 6A). The dissociation constant $\left(K_{d}\right)$ for oligomannose- 3 and oligomannose- 5 is about $20 \mathrm{nM}, 10$-fold higher than the affinity of FimH for oligomannose-6, -7, -8, and -9. The presence of Man5GlcNAc2-Asn N-glycosylation thus enables the FimH type-1 fimbrial adhesin to bind with the highest affinity (Bouckaert et al., 2006).

Subsequently, we infected intestinal epithelial cells with E. coli strains LF82 and K12-C600 in order to directly analyze the glycopeptides of CEACAM6. The typical LC-MS spectra of glycopeptides and its MS/MS fragmentation are shown in Figures 6B,C. From the obtained higher-energy collisional dissociation (HCD) fragmentation data, the proteome targeted against the CEACAM6 protein and the $N$-glycome were performed directly using Byonic ${ }^{\mathrm{TM}}$ v2.7.7 software. CEACAM6 had the highest score among all samples (Table S1). All Byonic ${ }^{\mathrm{TM}}$ annotated CEACAM6 glycopeptide-containing HCD spectra were inspected manually to verify the annotation.

In CEACAM6 recovered from both non-infected cells and cells infected with E. coli K12 or with E. coli LF82, two glycopeptides were detected despite low protein coverages: LQLSNGNMTLTLLSVK (191-206) and RNDAGSYECEIQNPASANR (207-225) (Table S1). HCD fragmentation did not detect these peptides in their nonglycosylated form, which means that they are frequently glycosylated. Indeed, the $N$-glycosylation sites on each peptide (Asn-197 and Asn-224) have been reported (Ramachandran et al., 2006; Chen et al., 2009).

Next we characterized the detected high-mannose type $N$-glycosylations on both asparagines (Table 1, Figures 6B,C). Interestingly, we have identified Man5GlcNAc2-Asn (Man5) on one of CEACAM6 glycopeptides, being a nanomolar-range carbohydrate ligand for FimH adhesins of type-1 fimbriated E. coli (Wellens et al., 2008).

Recombinant human CEACAM6 (rhCEACAM6) was chosen as a positive control sample of the CEACAM6 glycoprotein. By using enhanced filter-aided sample preparation (eFASP) on $50 \mu \mathrm{g}$ of rhCEACAM6, a sequence coverage of $90 \%$ was identified. Abundant glycosylation on several peptides was characterized, not only on the two peptides we discovered, LQLSNGNMTLTLLSVK (191-206) and RNDAGSYECEIQNPASANR (207-225), but also on other peptides: ETIYPNASLLIQNVTQNDTGFYTLQVIK (99126), SDLVNEEATGQFHVYPELPKPSISSNNSNPVEDK (127-160), and ANYRPGENLNLSC(Carbamidome thyl)HAASNPPAQYSWFINGTFQQSTQELFIPNIT

VNNSGSYMC(Carbamidomethyl)QAHNSATGLNR

(247-310). Interestingly, in LQLSNGNMTLTLLSVK (191-206), RNDAGSYECEIQNPASANR (207-225) and SDLVNEEATGQFHVYPELPKPSISSNNSNPVEDK 160), we identified high-mannose type glycans (Man5, Man6, Man7, Man8, and Man9) (Table 1), together with complex types 

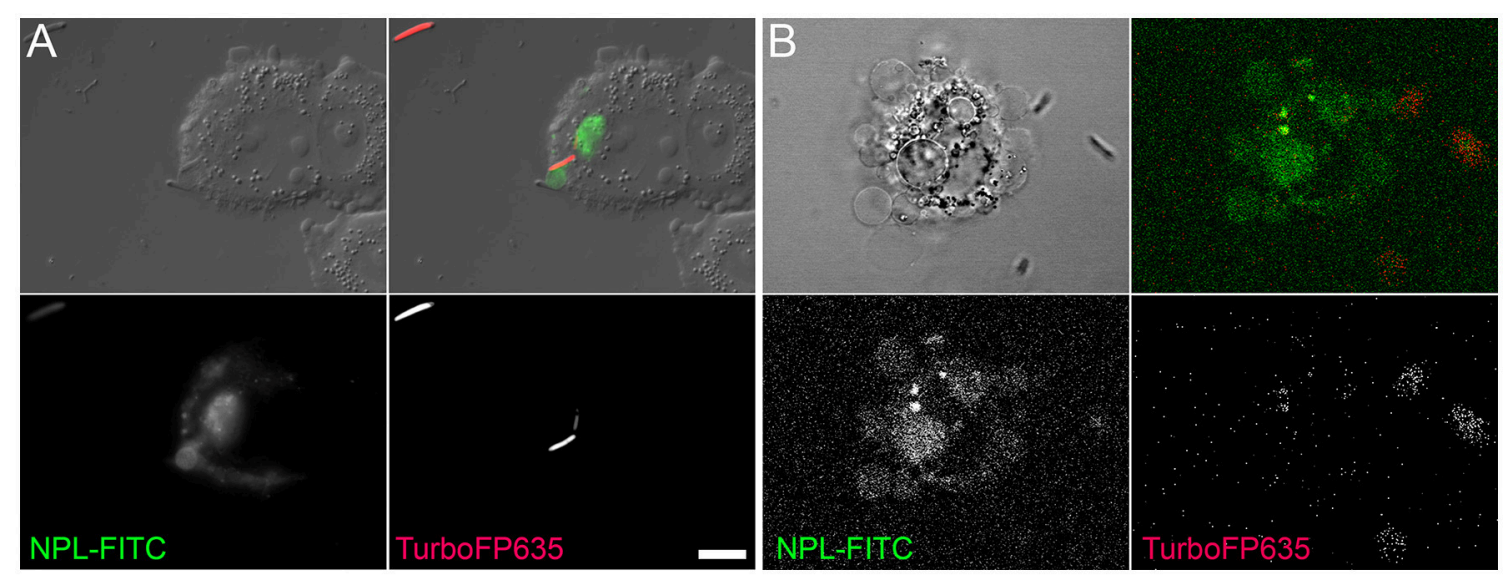

FIGURE 4 | AIEC LF82 preferentially binds ACMV from dying cells due to their high mannose content. (A) Fluorescent video microscopy of HeLa cells after $7 \mathrm{~h}$ of co-culture with AIEC. (B) Confocal microscopy of live Caco-2 cells induced to apoptosis by UV-B irradiation. ACMV rich in mannose glycans were visualized by NPL-FITC. The bacteria produced NIR-fluorescent protein TurboFP635. Scale bar $=5 \mu \mathrm{m}$.
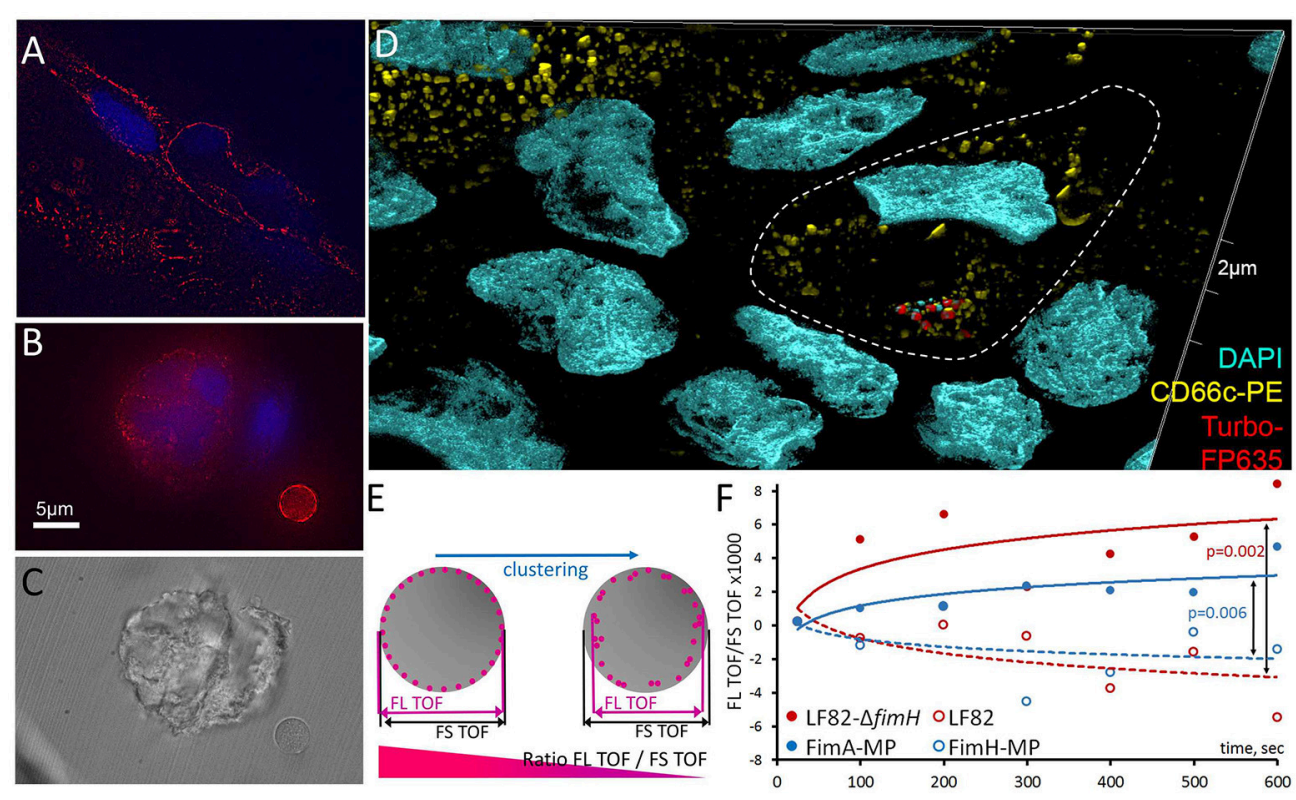

FIGURE $\mathbf{5}$ | CEACAM6 is involved in the initial binding of AIEC. The CEACAM6 glycoprotein is produced and distributed in clusters (A) on the surface of viable cells and $\mathbf{B}, \mathbf{C})$ on late apoptotic blebs or ACMV. (D) Structured illumination super-resolution microscopy of CEACAM6 clustering at the initial bacterial binding sites. (E,F) CEACAM6 forms clusters upon contact with the bacterial cells, or the FimH protein.

of glycosylation (Figure S5). Again, in the latter three peptides (191-206, 207-225, 127-160), over half of the peptides identified by HCD fragmentation were decorated with glycans, and in only one instance a non-glycosylated peptide was identified for the peptide LQLSNGNMTLTLLSVK (191-206). In the peptide ETIYPNASLLIQNVTQNDTGFYTLQVIK (99-126), we observed several types of glycan modifications, including the complex type $\mathrm{N}$-glycosylation and $\mathrm{O}$-glycosylation. As shown in Figure S5, two different complex type $\mathrm{N}$-glycosylations were found on this peptide, but no high-mannose type
$\mathrm{N}$-glycosylation. Although we observed many traces of glycan fragmentation on the peptide (ANYRPGENLNLSC(carbamid omethyl)HAASNPPAQYSWFINGTFQQSTQELFIPNITVNN

SGSYMC(carbamidomethyl)QAHNSATGLNR) (247-310), the peptide was too large $(\mathrm{m} / \mathrm{z}=7158)$ for complete characterization of its glycosylation.

Altogether, the results imply that the peptides we analyzed might carry both $\mathrm{N}$-linked and $\mathrm{O}$-linked glycosylation. Complete profiling of the $\mathrm{N}$-glycosylated peptides might require further digestion and electron-transfer dissociation 


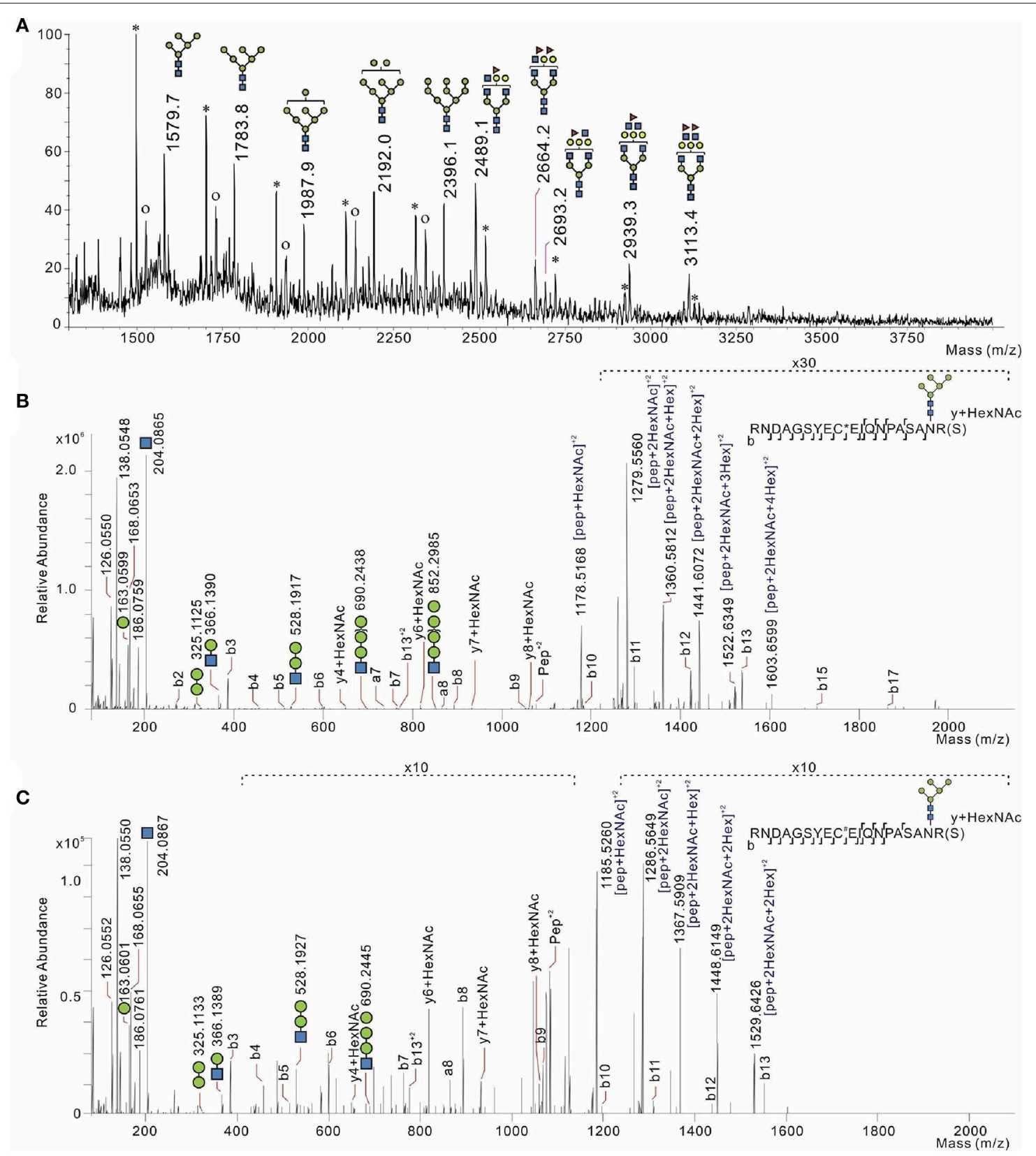

FIGURE 6 | Glycosylation analysis of CEACAM6 identified two oligomannose-bearing glycosylation sites serving as receptors for the bacterial adhesin FimH. (A) MALDI TOF/TOF $N$-glycosylation profile of CEACAM6 isolated from Caco-2 cells treated with IFN- $\gamma$. The asterisk indicates a polyhexose contamination. The symbol "o" means oxonium structures of each high mannose glycan structure. LC-MS/MS profiles of the glycopeptide either (B) from recombinant human CEACAM6 protein or (C) from CEACAM6 isolated from intestinal epithelial cells after exposure to AlEC LF82 bacteria. Peptides were found with cysteine modification,

(B) carbamidomethyl or (C) propionamide. Typical N-glycosylation (Man5GlcNAc2) was detected. Infection was for $3 \mathrm{~h}$ at a multiplicity of infection of 100 bacteria/cell.

(ETD) fragmentation analyses. Infection of intestinal epithelial cells with non-pathogenic E. coli K12-C600 or with the LF82 bacterial strain, followed by affinity isolation of CEACAM6, its fragmentation, and LC-MS/MS analysis demonstrated that bacterial interaction with host cells did not lead to modification of the protein sequence of CEACAM6. As shown in Figure S6, the experimental and theoretical isotopic patterns obtained for the glycopeptide LQLSNGNMTLTLLSVKR with $\mathrm{N}$ glycosylation $\operatorname{HexNAc}(2) \operatorname{Hex}(7)$ at $\mathrm{m} / \mathrm{z}=1143.5365, \mathrm{z}=3$ $\left(\mathrm{C}_{139} \mathrm{H}_{245} \mathrm{~N}_{26} \mathrm{O}_{7} 0 \mathrm{~S}_{1}\right)$ overlap perfectly $(-0.58 \mathrm{ppm}$ of error), confirming the identification of the glycopeptide within the high accuracy and resolution of the Orbitrap Q-Exactive Plus mass spectrometer. 
TABLE 1 | Presence of high mannose glycans on three different peptides.

\begin{tabular}{|c|c|c|c|c|c|c|}
\hline \multirow[t]{2}{*}{ Sample condition name of data } & \multicolumn{2}{|c|}{ Non-glycosylated peptide } & \multirow[t]{2}{*}{ Glycosylation } & \multicolumn{2}{|c|}{ Glycopeptide } & \multirow[t]{2}{*}{ Modification } \\
\hline & Rt (min) & Scan & & Rt (min) & Scan & \\
\hline \multicolumn{7}{|c|}{ PEPTIDE SEQUENCE-RNDAGSYEC(PROPIONAMIDE/CARBAMIDOMETHYL)EIQNPASANR } \\
\hline \multirow[t]{3}{*}{ inGel control CTRL_CEACAM6 } & - & - & Man5 & 32.909 & 6445 & C (carbamidomethyl) \\
\hline & & & Man6 & 32.851 & 6434 & C (propionamide) \\
\hline & & & Man7 & 32.934 & 6449 & C (propionamide) \\
\hline \multirow[t]{3}{*}{ inGel LF82 LF82_CEACAM6 } & - & - & Man5 & 33.219 & 6620 & C (carbamidomethyl) \\
\hline & & & Man6 & 32.955 & 6572 & C (carbamidomethyl) \\
\hline & & & Man7 & 32.950 & 6571 & C (propionamide) \\
\hline \multirow[t]{2}{*}{ inGel K12 K12_CEACAM6 } & - & - & Man5 & 33.220 & 6538 & C (propionamide) \\
\hline & & & Man6 & 32.809 & 6463 & C (carbamidomethyl) \\
\hline \multirow[t]{5}{*}{ eFASP recombinant rh_CEACAM6 } & 40.283 & 7041 & Man5 & 38.217 & 6709 & C (carbamidomethyl) \\
\hline & & & Man6 & 37.915 & 6661 & C (carbamidomethyl) \\
\hline & & & Man7 & 37.561 & 6605 & C (carbamidomethyl) \\
\hline & & & Man8 & 37.391 & 6577 & C (carbamidomethyl) \\
\hline & & & Man9 & 37.379 & 6575 & C (carbamidomethyl) \\
\hline \multicolumn{7}{|c|}{ PEPTIDE SEQUENCE－SDLVNEEATGQFHVYPELPKPSISSNNSNPVEDK } \\
\hline \multirow[t]{2}{*}{ eFASP recombinant rh_CEACAM6 } & 64.012 & 10872 & Man5 & 61.786 & 10515 & \\
\hline & & & Man7 & 61.486 & 10467 & \\
\hline \multicolumn{7}{|c|}{ PEPTIDE SEQUENCE-LQ*LSN*GN*MTLTLLSVKR *POTENTIAL DEAMIDATION SITE } \\
\hline \multirow[t]{3}{*}{ inGel control CTRL_CEACAM6 } & - & - & Man6 & 67.165 & 12836 & M (oxi) 1(deami) \\
\hline & & & Man7 & 67.044 & 12812 & M (oxi) 1(deami) \\
\hline & & & Man8 & 66.628 & 12732 & M (oxi) 2(deami) \\
\hline \multirow[t]{3}{*}{ inGel LF82 LF82_CEACAM6 } & - & - & Man6 & 67.461 & 12954 & M (oxi) 1(deami) \\
\hline & & & Man7 & 64.396 & 12376 & M (oxi) 1(deami) \\
\hline & & & Man8 & 74.040 & 14199 & 2(deami) \\
\hline \multirow[t]{3}{*}{ inGel K12 K12_CEACAM6 } & - & - & Man6 & 67.465 & 12835 & M (oxi) 1(deami) \\
\hline & & & Man7 & 67.111 & 12768 & M (oxi) 1(deami) \\
\hline & & & Man8 & 66.476 & 12642 & M (oxi) 2(deami) \\
\hline \multirow[t]{4}{*}{ eFASP recombinant rh_CEACAM6 } & 71.017 & 11999 & Man5 & 57.172 & 9769 & M(oxi) 1(deami) \\
\hline & & & Man6 & 57.188 & 9771 & M(oxi) 1(deami) \\
\hline & & & Man7 & 57.697 & 9853 & M(oxi) \\
\hline & & & Man8 & 63.419 & 10776 & \\
\hline
\end{tabular}

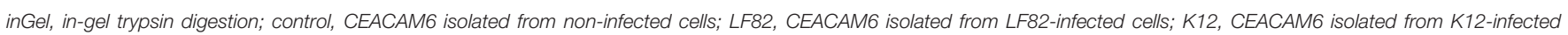

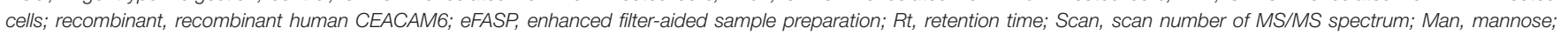
$M$, modification; oxi, oxidation; deami, deamidation (1 or 2 times on this peptide).

\section{DISCUSSION}

We propose that mannosidic glycans exposed on dying cells and on ACMV serve as an initial binding site for the AIEC LF82 lectin FimH. This proposal is based on the following: (1) our finding that dying cells expose binding targets for bacterial adhesins, (2) reports showing that multivalent binding of bacteria is required for host cell colonization (Weeks and Bouckaert, 2014; Yan et al., 2015) and (3) our data on the kinetics of AIEC localization and spreading. This FimH binding to mannosidic glycans is followed by recognition of CEACAM6 on the surface of intestinal epithelial cells in cis or trans. After initial binding by FimH, CEACAM6 clusters toward highly avid targets. A multivalent display of FimH, by covalently linking the FimCH chaperone-adhesin complex to microbeads, has been demonstrated previously as a requirement for its uptake into bladder cells (Martinez et al., 2000). After AIEC colonizes dying cells, which serve as an entry point into the epithelial layer, they move laterally through the membranes and colonize other neighboring cells. Initial binding of AIEC to cells might allow bacterial enzymes to cleave highly mannosylated glycans of CEACAM6 to produce an oligomannose-5 glycan that has the highest affinity for FimH. This could occur in cis or in trans. We previously reported trans cleavage by dying cells that desialylated their neighbors (Shkandina et al., 2012).

For UPEC, FimH first contacts bladder cells through uroplakin Ia (UPIa), which may induce apoptotic cell death mediated by inappropriate UPIIIa signaling (Zhou et al., 2001; Thumbikat et al., 2009). UPIa contains exclusively highmannosylated $N$-glycans with $6,7,8$, and 9 terminally exposed mannose residues (Xie et al., 2006). It has also been reported that UPEC can bind Gal( $(\beta 1-3)$ GalNac epitopes during chronic cystitis 
(Conover et al., 2016). Nevertheless, the identity of the receptors involved in the binding and penetration of AIEC into the host cell has not been fully explored yet. During AIEC infections and upon IFN- $\gamma$ pro-inflammatory stimulation, ceacam 6 expression is elevated in Caco-2 intestinal epithelial cells (Barnich et al., 2007). However, whether and how bacteria use this process for binding and invasion is unknown.

In CD patients, the intercellular space is more permeable and the regulation of tight junction proteins is disrupted (Turner, 2006). AIEC might exploit this weakness of the intestinal barrier for survival during CD manifestation, for otherwise they would be removed from the gut. Earlier (Brument et al., 2013), we reported that incubation of FimH with human Caco-2 cells led to only a moderate increase in the amount of apoptotic cells $(\sim 5 \%)$, which later underwent post-apoptotic, secondary necrosis. The same effect was observed in the current study when AIEC LF82 was incubated with human Caco-2 cells: after $5 \mathrm{~h}$ of co-infection followed by $19 \mathrm{~h}$ of co-incubation with gentamicin, most cells displayed bound bacteria, but only $\sim 5 \%$ of them became apoptotic (by $\mathrm{AxV}$ staining) or necrotic (by DRAQ7 permeability). This phenomenon has important biological significance: AIEC uses live epithelial cells expressing mannosylated CEACAM6 for initial colonization. In parallel, a few dying cells might serve as an "entry point" into the epithelial cell bilayer when oligomannosidic glycans are exposed during apoptosis. Here, we report that bacteria can move between adjacent cells, and we propose that this lateral mobility increases their invasive capacity.

Colonization and invasion by bacteria usually require contact with an appropriate receptor. CEACAM6 is known to bind AIEC and is involved in the initiation of intracellular signaling (Chassaing et al., 2011). Strong CEACAM6 production has been observed in CD patients (Barnich et al., 2007). It is overexpressed in various cancers (Farina et al., 2009; Riley et al., 2009; Chen et al., 2010), and its silencing prevents tumor growth (Gemei et al., 2013). CEACAM6 has been proposed as a diagnostic marker of diseases (Farina et al., 2014; Sharma et al., 2017). Cells transfected with ceacam6-overexpressing vectors show constitutive production of proteins of the growth cycle and lack cellular polarization (Ilantzis et al., 2002).

The CEACAM6 protein has 12 potential $N$-glycosylation sites (Hefta et al., 1990), and the corresponding glycopeptides display distinct molecular weights. Glycosylation at Asn-197 and Asn-224 has been reported (Ramachandran et al., 2006; Chen et al., 2009). In azurophilic granules in pathogen-infected sputa from individuals with cystic fibrosis, Thaysen-Andersen and coauthors identified a paucimannosidic glycan on CEACAM6 with 2 GlcNAc and 2 Man, with or without Fuc (Thaysen-Andersen et al., 2015). In our study, we discovered the presence of high mannose type glycan on three peptides (Asn152, Asn197, and Asn224). Despite the limited amounts of CEACAM6 obtained from in-gel digestion, the presence of high-mannose type glycans on both Asn197 and Asn224 agrees with those found in rhCEACAM6. Notably, these three sites are located on the same C2-set Ig-like domain, which is immediately after the V-set Iglike domain. Because we observed different types of glycosylation on other peptides of $\mathrm{V}$-set and on the other C2-set Ig-like domain, it would be interesting to investigate and confirm the presence of high-mannose type glycan on the first C2-set domain. We found no significant difference between the glycan types in non-infected and infected samples (Table 1).

FimH binds specifically to oligomannosidic glycans, and synthetic analogs of naturally occurring mannosidic glycans were shown to effectively block bacterial cell adhesion (Almant et al., 2011; Alvarez Dorta et al., 2016; Chalopin et al., 2016). The glycosylation changes on the surface of cells that occur during various pathological conditions may serve as important susceptibility factors for urinary tract infection (Taganna et al., 2011). We show that FimH lectin from E. coli can induce not only apoptosis but also the formation of ER-derived blebs that exhibit immature high-mannose glycans. The discovery of previously unknown ER-derived blebs bearing oligomannose glycoepitopes (Bilyy et al., 2012) makes them potential targets for the binding of $E$. coli FimH adhesin. Blockage of oligomannose glycoepitopes or their elimination may be exploited to prevent invasion of host cells by pathogenic E. coli.

\section{MATERIALS AND METHODS \\ Cell Culture}

Human cervical adenocarcinoma HeLa cells and human colorectal epithelial Caco-2 and T84 cells were obtained from the American Type Culture Collection (ATCC ${ }^{\circledR}$ CCL-2, HTB-37, CCL-248, respectively) and cultured in RPMI1640 and Eagle's Minimum Essential Medium (EMEM), respectively (Sigma Chemical Co., USA). The media were supplemented with $4 \mathrm{mM}$ L-glutamine, $10 \mathrm{mM}$ HEPES buffer, $100 \mathrm{U} / \mathrm{mL}$ penicillin, $100 \mu \mathrm{g} / \mathrm{mL}$ streptomycin (PAA, Pasching, Germany), and fetal calf serum (Gibco-BRL, Eggenstein, Germany) at $20 \%(\mathrm{v} / \mathrm{v})$ for Caco-2 cells and $10 \%$ for HeLa cells. Cultures were maintained under $5 \% \mathrm{CO}_{2}$ at $37^{\circ} \mathrm{C}$.

To detect surface exposure of phosphatidylserine and glycan, cells were stained with FITC-conjugated Annexin V (AxVFITC, Böhringer, Mannheim, Germany) and lectins (Vector Laboratories). The cells were grown on slides of $22 \times$ $22 \mathrm{~mm}$, washed twice with Ringer's solution, and placed in $200 \mu \mathrm{L}$ of reaction medium (Ringer's solution with 100 ng of AxV-FITC Nicoletti et al., 1991 or $1-5 \mu \mathrm{g} / \mathrm{mL}$ of lectins). The samples were analyzed immediately by fluorescence microscopy.

\section{Bacterial Strains and Growth}

E. coli laboratory K12-C600, UPEC UTI89, and AIEC LF82 strains were grown overnight at $37^{\circ} \mathrm{C}$ in Luria-Bertani broth with vigorous aeration. E. coli $\mathrm{K} 12-\mathrm{C} 600$ was purchased from the American Type Culture Collection (ATCC 23724). UTI89 is a human cystitis isolate (Chen et al., 2006). The E. coli LF82 was isolated from a chronic ileal lesion of a Crohn's disease patient (Darfeuille-Michaud et al., 1998). For in vitro studies, bacteria were diluted 100-fold and allowed to enter into the exponential growth phase, after which they were harvested by centrifugation, washed twice in Dulbecco's phosphate-buffered saline (DPBS). Microbiology experiments at LNMU, U1071, and UGSF were 
carried out at biosafety level 2 according to regulations for working with clinical material. Appropriate personal protective equipment is worn, including lab coats and gloves. All procedures (cells cultures, bacterial infection of eukaryotic cells) that can cause infection from aerosols or splashes are performed within a biological safety cabinet. An autoclave is available for proper disposals. The laboratories have self-closing, lockable doors. A sink and eyewash station should be readily available. Biohazard warning signs are exposed when necessary. Outside personnel are restricted from entering when work is being conducted.

\section{Co-culture of Epithelial Cells With Bacteria}

Cells were grown in culture medium to $60 \%$ confluence. Before infection, cells were washed twice with DPBS and the growth medium was replaced by Hank's balanced salt solution (HBSS) containing $1 \mathrm{~g} / \mathrm{L}$ of glucose. Bacteria were grown to an optical density of $\mathrm{OD}_{600 \mathrm{~nm}}=0.6-0.8$. Epithelial cells were infected with 50-100 bacteria per cell in HBSS lacking antibiotics and incubated for $5 \mathrm{~h}$ at $37^{\circ} \mathrm{C}$ under $5 \% \mathrm{CO}_{2}$. Next, they were washed three times with DPBS. Fresh HBSS containing $100 \mu \mathrm{g} / \mathrm{mL}$ of gentamicin was added to kill extracellular bacteria. After $1 \mathrm{~h}$ of incubation, host cells were washed twice with DPBS and either stained for microscopic analysis or incubated overnight with HBSS containing $15 \mu \mathrm{g} / \mathrm{mL}$ of gentamicin to assess bacterial infection. For microscopy, host cell membranes were stained using fluorescent wheat germ agglutinin (WGAFITC) (Vector Laboratories) at a final concentration of $5 \mu \mathrm{g} / \mathrm{mL}$, anti-CD66c-PE (phycoerythrin) (Affymetrix eBioscience) at a final concentration of $0.025 \mu \mathrm{g} / \mathrm{mL}$, and $1 \mu \mathrm{M}$ DAPI (SigmaAldrich).

\section{Induction of Cell Death and Detection of Apoptosis}

Apoptotic cells were used to study bacterial FimH binding to ER-derived blebs. Apoptosis was induced by bacterial lectin FimH conjugated with carboxylated polystyrene microparticles (Polysciences, Inc., USA) or by UV-B irradiation at $180 \mathrm{~mJ} / \mathrm{cm}^{2}$ for $90 \mathrm{~s}$. FimH lectin was purified from E. coli as described (Wellens et al., 2008). Apoptosis rate was measured by flow cytometry, and by fluorescence microscopy by counting the $\mathrm{AxV}$-positive cells using the ImageJ software.

\section{Flow Cytometry}

Flow cytometry was done using a Beckman Coulter Gallios flow cytometer according to the manufacturer's instructions. Data were analyzed with Kaluza software. CEACAM6 was detected using anti-human CD66C-PE (phycoerythrin) antibodies (Affymetrix eBiosciences) at a final concentration of $0.025 \mu \mathrm{g} / \mathrm{mL}$. Necrotic cells were detected by propidium iodide (PI) permeability. Apoptotic cells were detected as $\mathrm{AxV}-\mathrm{FITC}^{+} / \mathrm{PI}^{-}$cells. Among other features, apoptosis is characterized by blebbing of the cellular membrane, leading to a decrease in the forward scatter (FSC) and an increase in the sideward scatter (SSC). To detect phosphatidylserine exposure on the cell surface, cells were stained with FITCconjugated $\mathrm{AxV}$ in combination with PI (AxV/PI). 200,000 cells were stained for $30 \mathrm{~min}$ at $4^{\circ} \mathrm{C}$ with $200 \mathrm{ng}$ of $\mathrm{AxV}$ FITC and 500 ng PI in $500 \mu \mathrm{L}$ Ringer's solution (Maueröder et al., 2016). The samples were analyzed immediately by flow cytometry.

\section{Construction of Fluorescent Bacterial Strains}

The construction of the plasmid nadB::cat-kat for the expression of the katushka (TurboFP635) near-infrared fluorescent protein was described previously (Yan et al., 2015). E. coli LF82 transformed with the plasmid was selected by overnight culture at $37^{\circ} \mathrm{C}$ on LB-agar supplemented with kanamycin and chloramphenicol. Bacterial colonies turned pink after four or more days of incubation at room temperature, confirming the production of TurboFP635 fluorescent protein.

\section{Microscopy}

Fluorescence microscopy to observe DAPI, FITC-WGA, FITC-FimH, and FITC-AxV, PI, or the TurboFP635 protein expressed within E. coli, was done using a Zeiss AxioImager A1 Epifluorescence/DIC microscope equipped with an AxioCamMRm camera and corresponding fluorescence filters (all from Zeiss, Germany). Bright field signals were recorded with a conventional digital camera (Canon, Japan). In general, we performed 4-channel fluorescence microscopy (excitation maxima at 450, 515, 590, and $700 \mathrm{~nm}$ ) and simultaneous DIC differential interference contrast and light microscopy. Confocal microscopy was performed using a Carl Zeiss LSM 780 microscope equipped with five lasers $(405,458,488,514$, and $633 \mathrm{~nm})$. Fluorescent labeling of lectins was done according to the general principles of lectin chemistry and bioconjugate techniques, as described (Bilyy et al., 2009).

\section{Structured Illumination Super-Resolution Microscopy}

Structured illumination super-resolution microscopy (SIM) was performed using a Zeiss Axio Observer Z1 inverted microscope (Carl Zeiss, Germany) with a 63x/1.40 PLAN-APOCHROMAT objective. PALM-ELYRA PS1 lasers enable the excitation of probes at 405, 488, and $561 \mathrm{~nm}$.

Camera 1002x1004 EMCCD (Andor Technology Ltd., $\mathrm{UK}$ ) was used to acquire $15 \mathrm{SIM}$ images $(100 \mathrm{~nm} \mathrm{yx}$, $300 \mathrm{~nm} \mathrm{z}$ ) with five different phases for three different angular orientations of illumination for each SIM image). The images were processed with ZEN 2011 software (Carl Zeiss, Germany).

\section{Covalent Coupling of Proteins to Carboxylated Polystyrene Microparticles}

Covalent coupling of FimH and FimA lectin to Fluoresbrite ${ }^{\circledR}$ BB Carboxylate Microspheres $1.00 \mu \mathrm{m}$ (Polysciences, Inc., USA, catalog No. 17458) was done according to the manufacturer's protocol (TDS 238C). We used $0.25 \mathrm{~mL}$ of 
2.5\% carboxylated microparticles. After covalent coupling of FimH or FimA, the microparticles were resuspended in $0.25 \mathrm{~mL}$ storage buffer [1x phosphate-buffered saline (PBS), $1 \%$ bovine serum albumin, $0.1 \%$ sodium azide, $5 \%$ glycerol)]. In total, $0.88 \mathrm{mg}$ of FimH and $0.8 \mathrm{mg}$ of FimA protein were conjugated with $1 \mathrm{~mL}$ of microparticles containing $4.55 \times 10^{10}$ particles.

\section{Purification of CEACAM6}

Human CEACAM6 protein was extracted from T84 cells overproducing CEACAM6 using a Pierce Direct IP Kit (Thermo Scientific, USA, catalog No. 26148) according to the manufacturer's protocol, with some modifications. Briefly, T84 were seeded in $150-\mathrm{cm}^{2}$ at $2.5 \times 10^{7}$ cells per Petri dish. Cells were infected for $3 \mathrm{~h}$ with K12-C600 or AIEC LF82 at a multiplicity of infection of 100 bacteria per cell. Cell monolayers were extensively washed with PBS and the cells were lysed with IP lysis buffer (Pierce Direct IP kit). CEACAM6 was extracted from total cell lysates by immunoprecipitation with antibodies against the human CEACAM6 (mouse monoclonal antibody to 9A6 to CEACAM6, Aldevron, catalog No. GM-0509) immobilized on an agarose support (Figure S2).

\section{Analysis of ACMV Glycosylation by Mass Spectrometry}

Apoptotic cell death of Caco-2 cells was induced by FimH lectin (10 FimH-MP per cell) or UV-B irradiation followed by $4 \mathrm{~h}$ incubation. The ACMV pellet was collected after centrifugation at $18,000 \mathrm{rpm}(38,000 \times \mathrm{g})$ for $60 \mathrm{~min}$. Glycoproteins and glycolipids were separated by serial addition of chloroform/methanol in increasing ratios. Glycans from glycoproteins were released using $3 \mathrm{U}$ of PNGaseF ( $1 \mathrm{U} / \mu \mathrm{L}$, Roche) and purified on a $500-\mu \mathrm{L}$ graphite column (Alltech). Samples were permethylated by adding dimethyl sulfoxide, sodium hydroxide, and iodomethane. Samples were washed with water and then dried under a stream of nitrogen. Before analysis by MALDI mass spectrometry, samples were diluted in methanol, and 0.5 $\mu \mathrm{L}$ was mixed with $0.5 \mu \mathrm{L}$ of DHB matrix (2,5-dihydroxy benzoic acid in $50 \%$ acetonitrile and $0.1 \%$ trifluoroacetic acid solution).

\section{Enzymatic Release of $\mathbf{N}$-Glycans and Permethylation}

The purified CEACAM6 extracted and purified from the Caco2 cells was lyophilized and reconstituted in $4 \mathrm{mM}$ dithiothreitol and $6 \mathrm{M}$ guanidine hydrochloride in $50 \mathrm{mM}$ Tris- $\mathrm{HCl}, \mathrm{pH} 8$. Reduction was carried out for $20 \mathrm{~min}$ at $100^{\circ} \mathrm{C}$. After diluting the samples with $50 \mathrm{mM}\left(\mathrm{NH}_{4}\right) \mathrm{HCO}_{3}$ (ammonium bicarbonate) buffer, $\mathrm{pH} 8$, they were digested overnight at $37^{\circ} \mathrm{C}$ with trypsin (1 $\mu \mathrm{g}$ per sample, G-Bioscience, Agro-Bio, La Ferte St Aubin, France). Trypsin was inactivated at $-20^{\circ} \mathrm{C}$. The digests were applied on a column packed with $20 \mathrm{mg}$ of polymeric reversed phase Sepra ${ }^{\mathrm{TM}} \mathrm{ZT}$ sorbent (Phenomenex). The samples were eluted with 5, 65, and 100\% acetonitrile containing $0.1 \%$ trifluoroacetic acid. The peptide solution

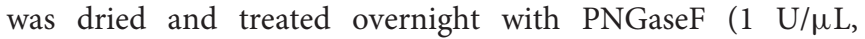
Roche).

Released $N$-glycans were recovered and purified using polymeric reversed phase Sepra ${ }^{\mathrm{TM}} \mathrm{ZT}$ sorbent. $N$-glycans that were not retained by the stationary-phase medium were recovered in $0.1 \%$ trifluoroacetic acid solution. An aliquot of each sample was permethylated using the sodium hydroxide/dimethyl sulfoxide reagent (Ciucanu and Kerek, 1984). The permethylated derivatives were extracted in chloroform and repeatedly washed with water. Permethylation is a common derivatization method used in glycomics and can overcome the problems associated with ionization of glycans and loss of acidic structures. Permethylation stabilizes glycans and prevents loss of sialic acid during ionization.

\section{Analysis by MALDI-TOF-MS}

Permethylated glycans were analyzed using a 4800+ Proteomics Analyzer MALDI-TOF/TOF (SCIEX, Framingham, MA, USA) in positive ion reflection mode with an accelerator voltage of $20 \mathrm{kV}$, a delay time of $200 \mathrm{~ns}$, and grid voltage at $66 \%$. The permethylated glycans were reconstituted in acetonitrile and 0.5 $\mu \mathrm{L}$ of each sample was spotted on the target plate and mixed with $0.5 \mu \mathrm{L}$ of matrix DHB (2,5-dihydroxy benzoic acid in $50 \%$ acetonitrile and $0.1 \%$ trifluoroacetic acid solution).

\section{Trypsin Enhanced Filter-Aided Sample Preparation (eFASP) Digestion of Recombinant Human Ceacam6 (rhCEACAM6)}

Ultrafilters from Amicon ${ }^{\circledR}(10 \mathrm{kDa}$ cutoff limit; Millipore, Billerica, MA) were incubated overnight in 5\% (v/v) Tween-20 (Sigma-Aldrich). Next, the filter units were rinsed thoroughly by three immersions in MS-grade water. eFASP digestion

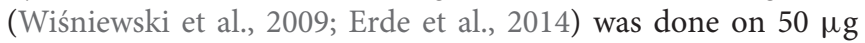
of samples estimated from a Bradford assay. The rhCEACAM6 sample (CE6-H5223, AcroBiosystems) was mixed overnight at $4^{\circ} \mathrm{C}$ with the reducing buffer [( $4 \%$ sodium dodecyl sulfate, $0.2 \%$ deoxycholic acid, $50 \mathrm{mM}$ dithiothreitol, $200 \mathrm{mM}\left(\mathrm{NH}_{4}\right) \mathrm{HCO}_{3}$, $\mathrm{pH}$ 8.0] and then centrifuged at $13,000 \times \mathrm{g}$ for $15 \mathrm{~min}$ at $20^{\circ} \mathrm{C}$. The filtrate was discarded, exchange buffer [ $8 \mathrm{M}$ urea, $0.2 \%$ deoxycholic acid, $100 \mathrm{mM}\left(\mathrm{NH}_{4}\right) \mathrm{HCO}_{3}$, pH 8.0] was deposited on each filter unit, and centrifugation was resumed for $30 \mathrm{~min}$. The reduced proteins were alkylated within the filter unit by adding alkylation buffer [ $8 \mathrm{M}$ urea, $50 \mathrm{mM}$ iodoacetamide and $100 \mathrm{mM}\left(\mathrm{NH}_{4}\right) \mathrm{HCO}_{3}, \mathrm{pH} 8.0$ ] and incubating the unit at $37^{\circ} \mathrm{C}$ for $1 \mathrm{~h}$ with shaking in the dark. The alkylation buffer was exchanged three times with eFASP digestion buffer [50 mM $\left(\mathrm{NH}_{4}\right) \mathrm{HCO}_{3}, 0.2 \%$ deoxycholic acid, $\mathrm{pH}$ 8.0]. Then, eFASP digestion buffer was added to each Amicon ${ }^{\circledR}$ unit, followed by $1 \mu \mathrm{g}$ of trypsin $(1: 50 \mathrm{w} / \mathrm{w})$. Digestion proceeded for $16 \mathrm{~h}$ at $37^{\circ} \mathrm{C}$. To complete peptide recovery, the filters were rinsed twice with the $50 \mathrm{mM}$ ammonium bicarbonate, $\mathrm{pH} 8.0$, which was collected by centrifugation. Next, trifluoroacetic acid was added and quickly vortexed. Peptide precipitates were mixed with ethyl acetate and centrifuged at $13,000 \mathrm{~g}$ for $10 \mathrm{~min}$. The organic supernatant was discarded and the step was repeated 
twice. Without disturbing the interface, as much of the upper organic layer as possible was removed and discarded. To remove residual ethyl acetate, the uncovered sample tube was placed in a thermomixer at $60^{\circ} \mathrm{C}$ in a fume hood for $5 \mathrm{~min}$. Residual organic solvent and volatile salts were removed by vacuum drying in a SpeedVac. This step was repeated twice with $50 \%$ methanol.

\section{In-Gel Trypsin Digestion of Extracted CEACAM6}

Cells were prepared under three conditions: no treatment of cells, and bacterial infection with K12 or LF82 for $3 \mathrm{~h}$ at a multiplicity of infection of 100. CEACAM6 attached to the beads of the affinity column was directly used for electrophoresis; the position of CEACAM6 on the gel was identified by comparison with the signal distribution in western blots. We used the antiCEACAM6 antibody (9A6, Aldevron, Germany, catalog No. GM-0509) because CEACAM6 did not stain well with Coomassie blue (Figure S2). The targeted position of the gel was cut in small pieces and washed three times with $25 \mathrm{mM}\left(\mathrm{NH}_{4}\right) \mathrm{HCO}_{3}$ containing $50 \%(\mathrm{v} / \mathrm{v})$ acetonitrile. Samples were dehydrated with acetonitrile and dried. The samples were reduced and alkylated by adding dithiotreitol and iodoacetamide, respectively. The gel pieces were washed with $25 \mathrm{mM}\left(\mathrm{NH}_{4}\right) \mathrm{HCO}_{3}$ containing $50 \%$ $(\mathrm{v} / \mathrm{v})$ acetonitrile, dehydrated with acetonitrile, and rehydrated in a digestion buffer containing $50 \mathrm{mM}\left(\mathrm{NH}_{4}\right) \mathrm{HCO}_{3}$ and 20 $\mathrm{ng} / \mu \mathrm{L}$ of trypsin (Promega, sequencing grade). The digested products were extracted and dried completely by vacuum centrifugation.

\section{Analysis of $\mathbf{N}$-Glycans by Liquid Chromatography-Tandem Mass Spectrometry (LC-MS/MS)}

A nanoflow HPLC instrument (U3000 RSLC Thermo Fisher Scientific) was coupled on-line to a QExactive plus (Thermo Scientific) with a nanoelectrospray ion source. $1 \mu \mathrm{L}$ of peptide mixture (corresponding to $200 \mathrm{ng}$ of proteins) was loaded onto the pre-concentration trap (Thermo Scientific, Acclaim PepMap100C18, $5 \mu \mathrm{m}, 300 \mu \mathrm{m}$ i.d. $\times 5 \mathrm{~mm}$ ) using partial loop injection for $5 \mathrm{~min}$ at a flow rate of $10 \mu \mathrm{L} / \mathrm{min}$ with buffer A (5\% acetonitrile and $0.1 \%$ formic acid). The peptides were separated on a column (Acclaim PepMap100 C18, $2 \mu \mathrm{m}$, $75 \mathrm{~mm}$ i.d. $\times 500 \mathrm{~mm}$ ) using a linear gradient of $5-50 \%$ buffer B $(75 \%$ acetonitrile and $0.1 \%$ formic acid) at a flow rate of $250 \mathrm{~nL} / \mathrm{min}$ at $45^{\circ} \mathrm{C}$. The total time for a LC MS/MS run was about $120 \mathrm{~min}$ and each sample was injected three times.

\section{Data Analysis: Identification of Glycosylation}

The acquired raw files were analyzed with Byonic $^{\mathrm{TM}}$ v2.7.7 (Protein Metrics Inc., San Carlos, CA, USA) to identify $N$-linked glycopeptides. The following parameters were used: CEACAM proteins of the Uniprot database (entry P40199 for human CEACAM6) (along with reversed proteins as decoys); tryptic peptides maximum three cleavages; mass accuracies within $15 \mathrm{ppm}$ for both precursor and fragment ions; carbamidomethylation of cysteine was set as a fixed modification. The variable modifications considered were (i) oxidation of methionine and proline, (ii) deamidation of asparagine and glutamine, and (iii) phosphorylation of serine and threonine. For glycosylation, the database of “ $N$-glycan human" including $57 \mathrm{~N}$-glycan masses was selected. The acceptance criterion was a false discovery rate on the protein level below 1\%. Peptide and glycan sequences were analyzed by ByonicTM from the HCD spectra and verified manually.

\section{SUMMARY}

Adherent-invasive Escherichia coli (AIEC) infects patients with ileal Crohn's disease. AIEC binds oligomannosidic cell surface receptors, penetrates into the cells, and can subsequently propagate within the epithelial layer. Whereas bacterial infections are correlated with an increased number of apoptotic cells, our results confirm that apoptotic cells may also serve as entry sites for pathogenic bacteria, from where they can spread to neighboring cells. Mass spectrometric characterization of carcinoembryonic antigen related cell adhesion molecule 6 (CEACAM6 or CD66c), a high-affinity receptor for the universal E. coli type-1 fimbrial adhesin, FimH, reveals oligomannosyl glycans at three different $N$-glycosylation sites. Unraveling the mechanism of the bacterial interaction with human intestinal epithelial cells will enable identification of compounds that specifically prevent AIEC adhesion without having a negative effect on other processes in the human body.

\section{AUTHOR CONTRIBUTIONS}

TD, JB, and RB: designed the study, and cultured and infected the cells; NY and BC: performed the MALDI MS/MS experiments; AS, EG, and NB: developed the CEACAM6 extraction and purification protocol; TD, NY, FB, and CR: performed the LCMS/MS and analyzed the data; TD, JB, AB, and FL: performed the super-resolution microscopy; CS: the confocal microscopy; $\mathrm{RB}, \mathrm{LM}$ and $\mathrm{MH}$ : carried out the flow cytometric analysis of clustered cell surface receptors; SR: performed structural analysis; SG: synthesized the FimH-specific inhibitors; SS, MH and AL: assisted with and provided feedback on the study, including on the cell culture and infection co-culture model; TD, AS, NY, RB, and JB: wrote the manuscript.

\section{FUNDING}

This work was supported by grants from the Ministry of Healthcare of Ukraine (project 0116U000759) and WUBMRC (to TD and RB), Horizon 2020 RISE project 690836 Pathogens and Graphene (TD, RB, JB, SS, LM, AL), VolksWagen Stiftung Grant No. 90361. This work benefited from support by the French Agence Nationale de la Recherche to JB, AS, NB, and SG (ANR12-BSV5-0016-01) and to FL (ANR-15-CE15-0017-03). MH and 
LM acknowledge support by Ardea Biosciences, Inc. and DFG grant KFO257. The proteomics facility was equiped with the help of the IBiSA Infrastructure en Biologie Santé Agronomie network and the Région Hauts-de-France.

\section{ACKNOWLEDGMENTS}

We are grateful for access to the microscope facilities of the BioImaging Center, BICeL. We thank the Plateforme d'Analyse

\section{REFERENCES}

Almant, M., Moreau, V., Kovensky, J., Bouckaert, J., and Gouin, S. G. (2011). Clustering of Escherichia coli type-1 fimbrial adhesins by using multimeric heptyl alpha-D-mannoside probes with a carbohydrate core. Chemistry 17, 10029-10038. doi: 10.1002/chem.201100515

Alvarez Dorta, D., Sivignon, A., Chalopin, T., Dumych, T. I., Roos, G., Bilyy, R. O., et al. (2016). The antiadhesive strategy in Crohn's disease: orally active mannosides to decolonize pathogenic Escherichia coli from the gut. Chembiochem 17, 936-952. doi: 10.1002/cbic.201600018

Barnich, N., Carvalho, F. A., Glasser, A.-L., Darcha, C., Jantscheff, P., Allez, M., et al. (2007). CEACAM6 acts as a receptor for adherent-invasive E. coli, supporting ileal mucosa colonization in Crohn disease. J. Clin. Invest. 117, 1566-1574. doi: 10.1172/JCI30504

Bilyy, R. O., Shkandina, T., Tomin, A., Muñoz, L. E., Franz, S., Antonyuk, V., et al. (2012). Macrophages discriminate glycosylation patterns of apoptotic cell-derived microparticles. J. Biol. Chem. 287, 496-503. doi: 10.1074/jbc.M111.273144

Bilyy, R., Tomyn, A., Kit, Y., Podhorodecki, A., Misiewicz, J., Nyk, M., et al. (2009). Detection of dying cells using lectin-conjugated fluorescent and luminescent nanoparticles. Materwiss. Werksttech. 40, 234-237. doi: 10.1002/mawe.200900432

Bouckaert, J., Mackenzie, J., De Paz, J. L., Chipwaza, B., Choudhury, D., Zavialov, A., et al. (2006). The affinity of the FimH fimbrial adhesin is receptor-driven and quasi-independent of Escherichia coli pathotypes. Mol. Microbiol. 61, 1556-1568. doi: 10.1111/j.1365-2958.2006.05352.x

Brument, S., Sivignon, A., Dumych, T. I., Moreau, N., Roos, G., Guérardel, Y., et al. (2013). Thiazolylaminomannosides as potent antiadhesives of type 1 piliated Escherichia coli isolated from crohn's disease patients. J. Med. Chem. 56, 5395-5406. doi: 10.1021/jm400723n

Chalopin, T., Alvarez Dorta, D., Sivignon, A., Caudan, M., Dumych, T. I., Bilyy, R. O., et al. (2016). Second generation of thiazolylmannosides, FimH antagonists for E. coli-induced Crohn's disease. Org. Biomol. Chem. 14, 3913-3925. doi: $10.1039 /$ c6ob00424e

Chassaing, B., Darfeuille-Michaud, A., and Darfeuille-Michaud, A. (2011). The commensal microbiota and enteropathogens in the pathogenesis of inflammatory bowel diseases. Gastroenterology 140, 1720-1728. doi: 10.1053/j.gastro.2011.01.054

Chen, J.-S., Chen, K.-T., Fan, C.-W., Han, C.-L., Chen, Y.-J., Yu, J.-S., et al. (2010). Comparison of membrane fraction proteomic profiles of normal and cancerous human colorectal tissues with gel-assisted digestion and iTRAQ labeling mass spectrometry. FEBS J. 277, 3028-3038. doi: 10.1111/j.1742-4658.2010.0 7712.x

Chen, R., Jiang, X., Sun, D., Han, G., Wang, F., Ye, M., et al. (2009). Glycoproteomics analysis of human liver tissue by combination of multiple enzyme digestion and hydrazide chemistry. J. Proteome Res. 8, 651-661. doi: $10.1021 /$ pr8008012

Chen, S. L., Hung, C. S., Xu, J. A., Reigstad, C. S., Magrini, V., Sabo, A., et al. (2006). Identification of genes subject to positive selection in uropathogenic strains of Escherichia coli: a comparative genomics approach. Proc. Natl. Acad. Sci. U.S.A. 103, 5977-5982. doi: 10.1073/pnas.0600938103

Ciucanu, I., and Kerek, F. (1984). A simple and rapid method for the permethylation of carbohydrates. Carbohydr. Res. 131, 209-217. doi: 10.1016/0008-6215(84)85242-8 des Glycoconjugués (PAGés, http://plateforme-pages.univ-lille1. fr/) for providing the technical environment conducive to achieving this work.

\section{SUPPLEMENTARY MATERIAL}

The Supplementary Material for this article can be found online at: https://www.frontiersin.org/articles/10.3389/fmicb. 2018.00742/full\#supplementary-material

Conover, M. S., Ruer, S., Taganna, J., Kalas, V., De Greve, H., Pinkner, J. S., et al (2016). Inflammation-induced adhesin-receptor interaction provides a fitness advantage to uropathogenic, E. coli during chronic infection. Cell Host Microbe 20, 482-492. doi: 10.1016/j.chom.2016.08.013

Conte, M. P., Aleandri, M., Marazzato, M., Conte, A. L., Ambrosi, C., Nicoletti, M., et al. (2016). The adherent/invasive Escherichia coli strain LF82 invades and persists in human prostate cell line RWPE-1, activating a strong inflammatory response. Infect. Immun. 84, 3105-3113. doi: 10.1128/IAI.00438-16

Darfeuille-Michaud, A., Boudeau, J., Bulois, P., Neut, C., Glasser, A.-L. L., Barnich, N., et al. (2004). High prevalence of adherent-invasive Escherichia coli associated with ileal mucosa in Crohn's disease. Gastroenterology 127, 412-421. doi: 10.1053/j.gastro.2004.04.061

Darfeuille-Michaud, A., Neut, C., Barnich, N., Lederman, E., Di Martino, P., Desreumaux, P., et al. (1998). Presence of adherent Escherichia coli strains in ileal mucosa of patients with Crohn's disease. Gastroenterology 115, 1405-1413.

Erde, J., Loo, R. R. O., and Loo, J. A. (2014). Enhanced FASP (eFASP) to increase proteome coverage and sample recovery for quantitative proteomic experiments. J. Proteome Res. 13, 1885-1895. doi: 10.1021/pr4010019

Farina, A., Dumonceau, J.-M., Antinori, P., Annessi-Ramseyer, I., Frossard, J.-L., Hochstrasser, D. F., et al. (2014). Bile carcinoembryonic cell adhesion molecule 6 (CEAM6) as a biomarker of malignant biliary stenoses. Biochim. Biophys. Acta 1844, 1018-1025. doi: 10.1016/j.bbapap.2013.06.010

Farina, A., Dumonceau, J.-M., Frossard, J.-L., Hadengue, A., Hochstrasser, D. F., and Lescuyer, P. (2009). Proteomic analysis of human bile from malignant biliary stenosis induced by pancreatic cancer. J. Proteome Res. 8, 159-169. doi: $10.1021 /$ pr8004925

Fürnrohr, B. G., Stein, M., Rhodes, B., Chana, P. S., Schett, G., Vyse, T. J., et al. (2015). Reduced fluorescence versus forward scatter time-of-flight and increased peak versus integral fluorescence ratios indicate receptor clustering in flow cytometry. J. Immunol. 195, 377-385. doi: 10.4049/jimmunol.1401889

Geerlings, S. E., Meiland, R., van Lith, E. C., Brouwer, E. C., Gaastra, W., and Hoepelman, A. I. M. (2002). Adherence of type 1-fimbriated Escherichia coli to uroepithelial cells: more in diabetic women than in control subjects. Diabetes Care 25, 1405-1409. doi: 10.2337/diacare.25.8.1405

Gemei, M., Mirabelli, P., Di Noto, R., Corbo, C., Iaccarino, A., Zamboli, A. et al. (2013). CD66c is a novel marker for colorectal cancer stem cell isolation, and its silencing halts tumor growth in vivo. Cancer 119, 729-738. doi: $10.1002 / \mathrm{cncr} .27794$

Hefta, S. A., Paxton, R. J., and Shively, J. E. (1990). Sequence and glycosylation site identity of two distinct glycoforms of nonspecific cross-reacting antigen as demonstrated by sequence analysis and fast atom bombardment mass spectrometry. J. Biol. Chem. 265, 8618-8626.

Hultgren, S. J., Normark, S., and Abraham, S. N. (1991). Chaperone-assisted assembly and molecular architecture of adhesive pili. Annu. Rev. Microbiol. 45, 383-415. doi: 10.1146/annurev.mi.45.100191.002123

Ilantzis, C., DeMarte, L., Screaton, R. A., and Stanners, C. P. (2002). Deregulated expression of the human tumor marker CEA and CEA family member CEACAM6 disrupts tissue architecture and blocks colonocyte differentiation. Neoplasia 4, 151-163. doi: 10.1038/sj.neo.7900201

Kline, K. A., Fälker, S., Dahlberg, S., Normark, S., and Henriques-Normark, B. (2009). Bacterial adhesins in host-microbe interactions. Cell Host Microbe 5, 580-592. doi: 10.1016/j.chom.2009.05.011

Klumpp, D. J., Rycyk, M. T., Chen, M. C., Thumbikat, P., Sengupta, S., and Schaeffer, A. J. (2006). Uropathogenic Escherichia coli induces extrinsic and 
intrinsic cascades to initiate urothelial apoptosis. Infect. Immun. 74, 5106-5113. doi: 10.1128/IAI.00376-06

Laupland, K. B., Ross, T., Pitout, J. D. D., Church, D. L., and Gregson, D. B. (2007). Community-onset urinary tract infections: a population-based assessment. Infection 35, 150-153. doi: 10.1007/s15010-007-6180-2

Martinez, J. J., Mulvey, M. A., Schilling, J. D., Pinkner, J. S. and Hultgren, S. J. (2000). Type 1 pilus-mediated bacterial invasion of bladder epithelial cells. EMBO J. 19, 2803-2812. doi: 10.1093/emboj/19.12.2803

Maueröder, C., Chaurio, R. A., Dumych, T., Podolska, M., Lootsik, M. D., Culemann, S., et al. (2016). A blast without power - cell death induced by the tuberculosis-necrotizing toxin fails to elicit adequate immune responses. Cell Death Differ. 23, 1016-1025. doi: 10.1038/cdd.2016.4

Miquel, S., Peyretaillade, E., Claret, L., de Vallée, A., Dossat, C., Vacherie, B., et al. (2010). Complete genome sequence of Crohn's diseaseassociated adherent-invasive E. coli strain LF82. PLoS ONE 5:e12714. doi: 10.1371/journal.pone.0012714

Mysorekar, I. U., Isaacson-Schmid, M., Walker, J. N., Mills, J. C., and Hultgren, S. J. (2009). Bone morphogenetic protein 4 signaling regulates epithelial renewal in the urinary tract in response to uropathogenic infection. Cell Host Microbe 5, 463-475. doi: 10.1016/j.chom.2009.04.005

Nicoletti, I., Migliorati, G., Pagliacci, M. C., Grignani, F., and Riccardi, C. (1991). A rapid and simple method for measuring thymocyte apoptosis by propidium iodide staining and flow cytometry. J. Immunol. Methods 139, 271-279. doi: 10.1016/0022-1759(91)90198-O

Ramachandran, P., Boontheung, P., Xie, Y., Sondej, M., Wong, D. T., and Loo, J. A. (2006). Identification of N-linked glycoproteins in human saliva by glycoprotein capture and mass spectrometry. J. Proteome Res. 5, 1493-1503. doi: $10.1021 /$ pr050492k

Riley, C. J., Engelhardt, K. P., Saldanha, J. W., Qi, W., Cooke, L. S., Zhu, Y., et al. (2009). Design and activity of a murine and humanized anti-CEACAM6 singlechain variable fragment in the treatment of pancreatic cancer. Cancer Res. 69, 1933-1940. doi: 10.1158/0008-5472.CAN-08-2707

Sharma, N., Srivastava, S., Kern, F., Xian, W., Yeoh, K. G., Ming, T., et al. (2017). CEACAM 6, a novel marker for the diagnosis of Barrett's esophagus. Dis. Esophagus 30, 1-5. doi: 10.1093/dote/dox026

Shkandina, T., Herrmann, M., and Bilyy, R. (2012). Sweet kiss of dying cell: sialidase activity on apoptotic cell is able to act toward its neighbors. Autoimmunity 45, 574-578. doi: 10.3109/08916934.2012.719951

Stamm, W. E. (2002). Scientific and clinical challenges in the management of urinary tract infections. Am. J. Med. 113(Suppl.1A), 1S-4S. doi: 10.1016/S0002-9343(02)01053-7

Taganna, J., de Boer, A. R., Wuhrer, M., and Bouckaert, J. (2011). Glycosylation changes as important factors for the susceptibility to urinary tract infection. Biochem. Soc. Trans. 39, 349-354. doi: 10.1042/BST0390349

Thaysen-Andersen, M., Venkatakrishnan, V., Loke, I., Laurini, C., Diestel, S., Parker, B. L., et al. (2015). Human neutrophils secrete bioactive paucimannosidic proteins from azurophilic granules into pathogen-infected sputum. J. Biol. Chem. 290, 8789-8802. doi: 10.1074/jbc.M114.631622

Thompson, J. A., Grunert, F., and Zimmermann, W. (1991). Carcinoembryonic antigen gene family: molecular biology and clinical perspectives. J. Clin. Lab. Anal. 5, 344-366. doi: 10.1002/jcla.1860050510
Thumbikat, P., Berry, R. E., Zhou, G., Billips, B. K., Yaggie, R. E., Zaichuk, T., et al. (2009). Bacteria-induced uroplakin signaling mediates bladder response to infection. PLoS Pathog. 5:e1000415. doi: 10.1371/journal.ppat.10 00415

Tomin, A., Dumych, T., Tolstyak, Y., Kril, I., Mahorivska, I., Bila, E., et al. (2015). Desialylation of dying cells with catalytically active antibodies possessing sialidase activity facilitate their clearance by human macrophages. Clin. Exp. Immunol. 179, 17-23. doi: 10.1111/cei.12312

Turner, J. R. (2006). Molecular basis of epithelial barrier regulation: from basic mechanisms to clinical application. Am. J. Pathol. 169, 1901-1909. doi: 10.2353/ajpath.2006.060681

van der Pol, E., Böing, A. N., Harrison, P., Sturk, A., and Nieuwland, R. (2012). Classification, functions, and clinical relevance of extracellular vesicles. Pharmacol. Rev. 64, 676-705. doi: 10.1124/pr.112.005983

Weeks, S. D., and Bouckaert, J. (2014). Small-angle X-ray scattering to obtain models of multivalent lectin-glycan complexes. Methods Mol. Biol. 1200, 511-526. doi: 10.1007/978-1-49391292-6_42

Wellens, A., Garofalo, C., Nguyen, H., Van Gerven, N., Slattegard, R., Hernalsteens, J.-P. P., et al. (2008). Intervening with urinary tract infections using antiadhesives based on the crystal structure of the FimH-oligomannose- 3 complex. PLoS ONE 3:e2040. doi: 10.1371/annotation/ea59d179-0a71-4836-86f0-8d375 f5df089

Wiśniewski, J. R., Zougman, A., Nagaraj, N., and Mann, M. (2009). Universal sample preparation method for proteome analysis. Nat. Methods 6, 359-362. doi: $10.1038 /$ nmeth.1322

Xie, B., Zhou, G., Chan, S.-Y., Shapiro, E., Kong, X.-P., Wu, X.-R., et al. (2006). Distinct glycan structures of uroplakins Ia and Ib: structural basis for the selective binding of FimH adhesin to uroplakin Ia. J. Biol. Chem. 281, 14644-14653. doi: 10.1074/jbc.M600877200

Yan, X., Sivignon, A., Yamakawa, N., Crepet, A., Travelet, C., Borsali, R., et al. (2015). Glycopolymers as antiadhesives of E. coli strains inducing inflammatory bowel diseases. Biomacromolecules 16, 1827-1836. doi: 10.1021/acs.biomac.5b00413

Zhou, G., Mo, W. J., Sebbel, P., Min, G., Neubert, T. A., Glockshuber, R., et al. (2001). Uroplakin Ia is the urothelial receptor for uropathogenic Escherichia coli: evidence from in vitro FimH binding. J. Cell Sci. 114, 4095-4103.

Conflict of Interest Statement: The authors declare that the research was conducted in the absence of any commercial or financial relationships that could be construed as a potential conflict of interest.

Copyright (c) 2018 Dumych, Yamakawa, Sivignon, Garenaux, Robakiewicz, Coddeville, Bongiovanni, Bray, Barnich, Szunerits, Slomianny, Herrmann, Gouin, Lutsyk, Munoz, Lafont, Rolando, Bilyy and Bouckaert. This is an open-access article distributed under the terms of the Creative Commons Attribution License (CC $B Y)$. The use, distribution or reproduction in other forums is permitted, provided the original author(s) and the copyright owner are credited and that the original publication in this journal is cited, in accordance with accepted academic practice. No use, distribution or reproduction is permitted which does not comply with these terms. 